\title{
Archaeological Investigations of the Proposed Convention Center and City Hall Project Area in Downtown Bastrop, Bastrop County, Texas
}

Jon J. Dowling

Follow this and additional works at: https://scholarworks.sfasu.edu/ita

Part of the American Material Culture Commons, Archaeological Anthropology Commons, Environmental Studies Commons, Other American Studies Commons, Other Arts and Humanities Commons, Other History of Art, Architecture, and Archaeology Commons, and the United States History Commons

Tell us how this article helped you.

This Article is brought to you for free and open access by the Center for Regional Heritage Research at SFA ScholarWorks. It has been accepted for inclusion in Index of Texas Archaeology: Open Access Gray Literature from the Lone Star State by an authorized editor of SFA ScholarWorks. For more information, please contact cdsscholarworks@sfasu.edu. 
Archaeological Investigations of the Proposed Convention Center and City Hall Project Area in Downtown Bastrop, Bastrop County, Texas

\section{Creative Commons License}

\section{(c) (1) \&}

This work is licensed under a Creative Commons Attribution-NonCommercial 4.0 International License 


\section{Archaeological Investigations of the Proposed Convention Center and City Hall Project Area in Downtown Bastrop, Bastrop County, Texas}

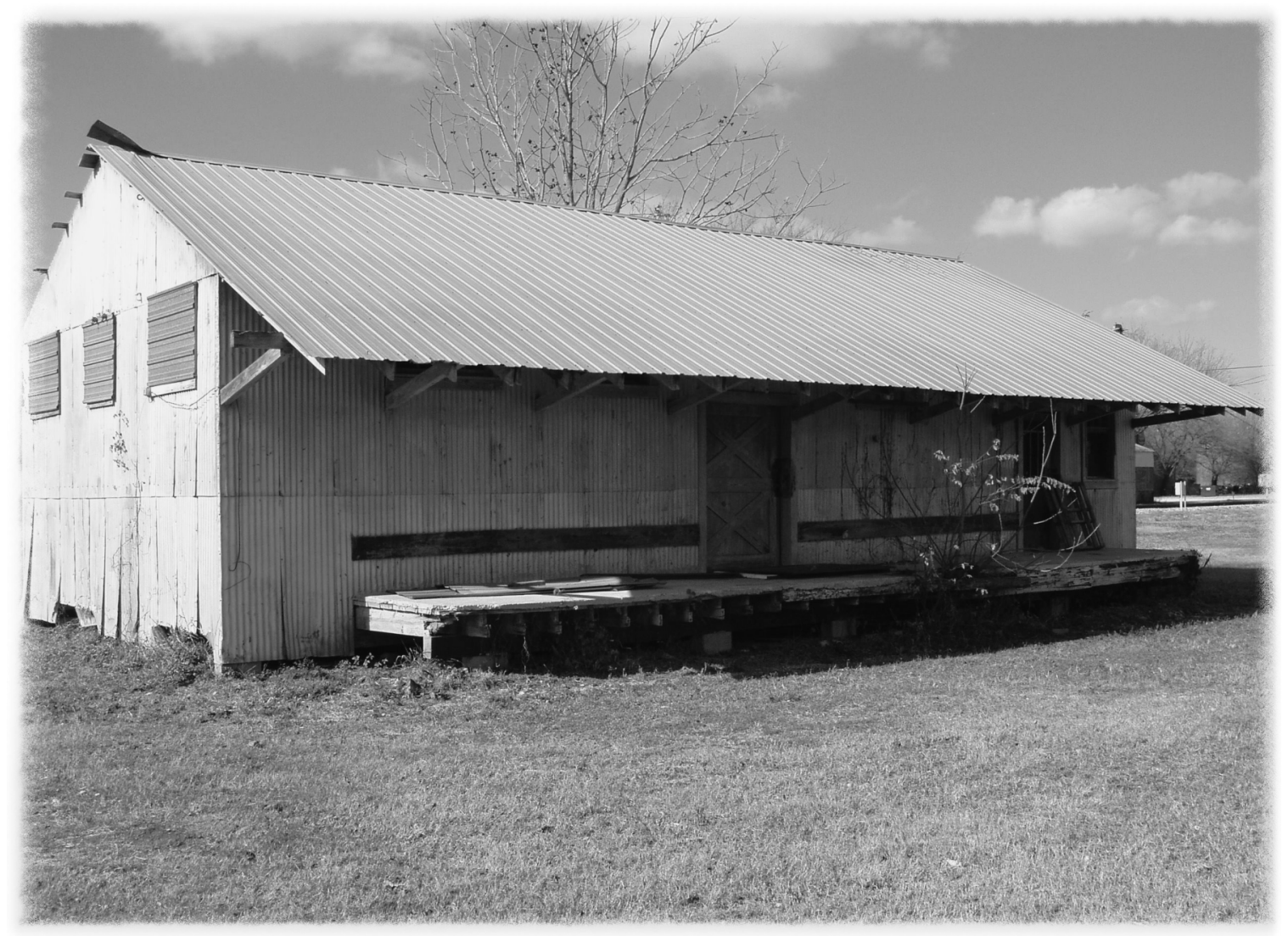

Prepared for:

City of Bastrop

Office of the City Manager

904 Main Street, P.O. Box 427

Bastrop, TX 78602

\author{
by \\ Jon J. Dowling \\ with a contribution by \\ Theresa de la Garza Carwise
}

Texas Antiquities Permit No. 4867

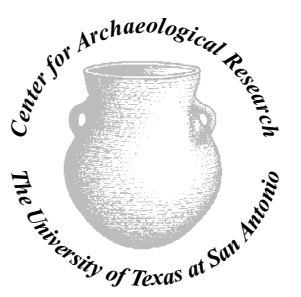

(C)2008
Prepared by:

Center for Archaeological Research The University of Texas at San Antonio Archaeological Report, No. 386 


\title{
Archaeological Investigations of the Proposed Convention Center and City Hall Project Area in Downtown Bastrop, Bastrop County, Texas
}

\author{
by \\ Jon J. Dowling \\ with a contribution by \\ Theresa de la Garza Carwise
}

Texas Antiquities Committee Permit No. 4867

Prepared for:

City of Bastrop, Office of City Manager

904 Main Street, P.O. Box 427

Bastrop, Texas 78602

\section{Principal Investigator \\ Cynthia M. Munoz}

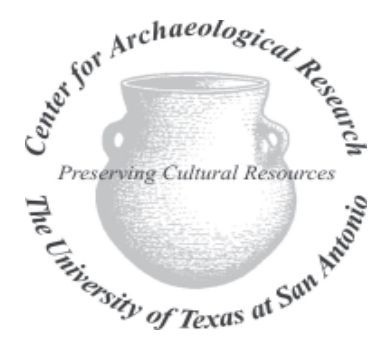

Prepared by:

Center for Archaeological Research The University of Texas at San Antonio Archaeological Report No. 386 



\begin{abstract}
:
In April of 2008, the Center for Archaeological Research (CAR) at The University of Texas at San Antonio (UTSA) carried out an intensive archaeological pedestrian survey and standing historic resources assessment of the proposed Bastrop Convention Center and City Hall project area for the City of Bastrop, Office of the City Manager. Since the proposed project will impact land owned by the City of Bastrop, a political subdivision of the State of Texas, it falls under the jurisdiction of the Antiquities Code of Texas administered by the Texas Historical Commission.
\end{abstract}

The purpose of this investigation was to determine the presence and location of any archaeological deposits or standing historic resources by means of reconnaissance walk-over survey, systematic shovel testing, and backhoe trenching within four city blocks of Bastrop's Downtown Historic District. Concentrated investigative efforts revealed the presence of historic archaeological site 41BP837 and a historic railway depot structure, 41BP839, in the western portion of the project area, adjacent to the railroad. The presence of an historic residential structure was also ascertained on Block 69 in the eastern section of the project area. The CAR recommended that neither 41BP837 nor the historic residential structure on Block 69 are eligible for the National Register of Historic Places (NRHP). However, the CAR recommended the historic depot, 41BP839, as eligible for the NRHP.

The Texas Historical Commission (THC), upon review of this report, concluded that due to substantive modification, the historic railway depot, 41BP839, is not eligible for the NRHP. Furthermore, the THC recommended additional in depth archival research for both Blocks 53 and 69 to determine the exact date of origins of structures shown on the Koch 1887 bird's eye map. Because this research ascertained that both blocks contained structures dating prior to 1880, the THC recommended that additional testing at the locations of these structures on Blocks 53 and 69 is warranted.

Archaeological survey of the project area was performed under Texas Antiquities Permit No. 4867 under contract with the City of Bastrop, Office of the City Manager. Cynthia M. Munoz served as Principal Investigator, with Jon J. Dowling serving as Project Archaeologist. All artifacts and records generated during this field endeavor are curated at the Center for Archaeological Research according to Texas Historical Commission guidelines. 


\section{Table of Contents:}

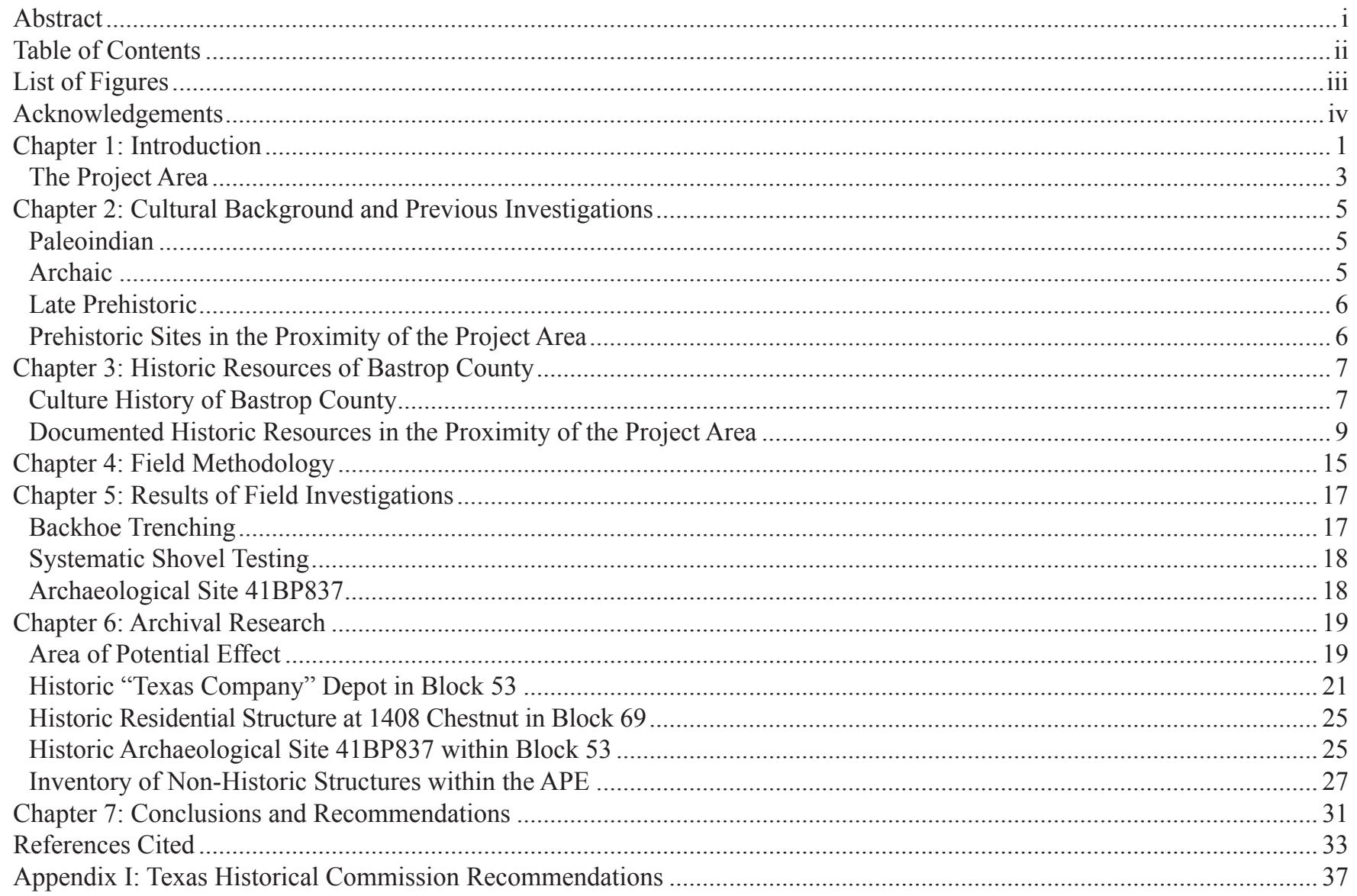




\section{List of Figures:}

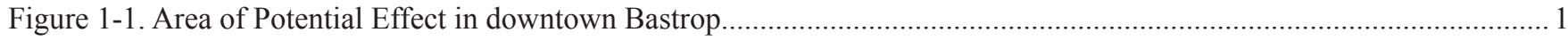

Figure 1-2. APE Blocks 52, 53, 69 and 70

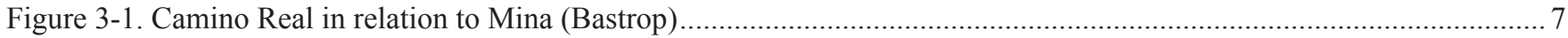

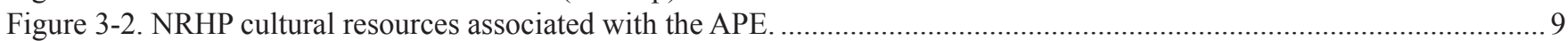

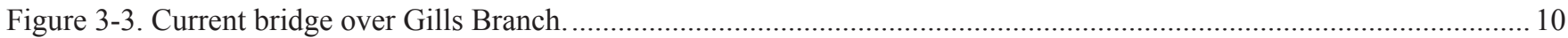

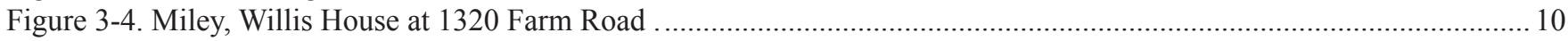

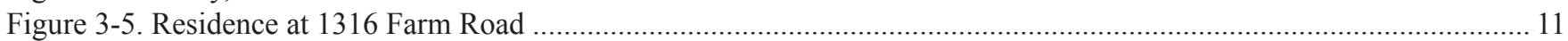

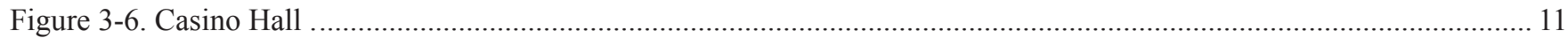

Figure 3-7. Former location of absent M.K.T. Depot.

Figure 3-8. Old photograph of M.K.T. Depot with still standing landmarks in background. ............................................... 12

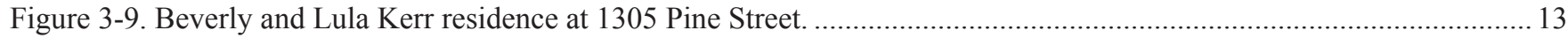

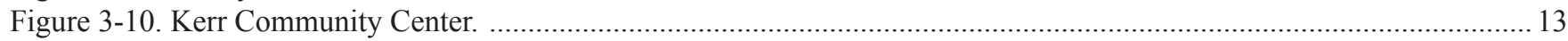

Figure 3-11. Recorded historic archaeological sites near the project area........................................................................ 14

Figure 4-1. GPS locations of 27 excavated shovel tests, 3 backhoe trenches, and archaeological sites 41 BP837 and 41BP839

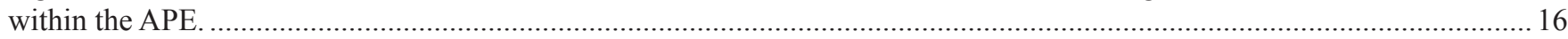

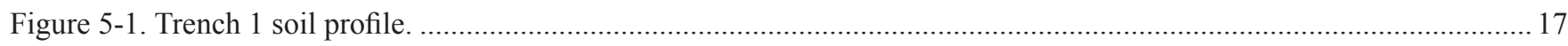

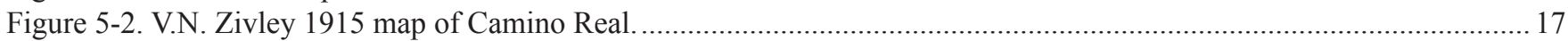

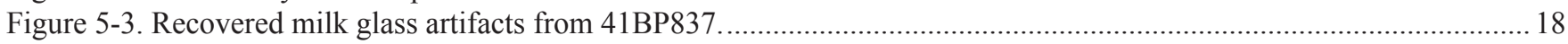

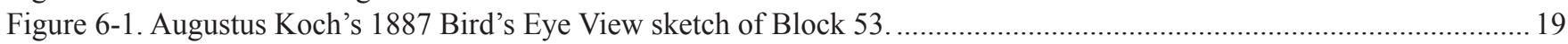

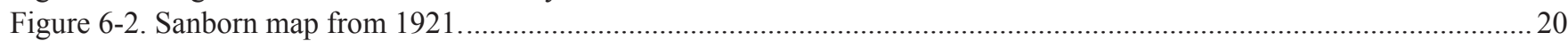

Figure 6-3. Sanborn map from 1934

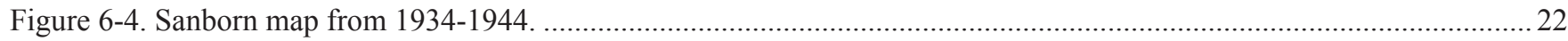

Figure 6-5. "Texas Company” structure in southwest quadrant of Block 53 .....................................................................2

Figure 6-6. Company title adorning "The Texas Company" structure. …….....................................................................23

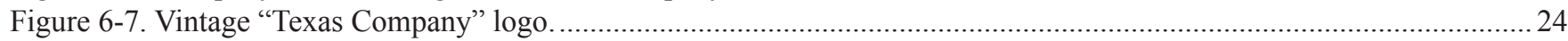

Figure 6-8. Aerial of APE illustrating the seven registered addresses within the project area............................................24

Figure 6-9. Foundation network of cinderblocks and beams under "Texas Company" structure. …....................................25

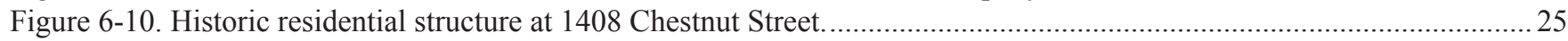

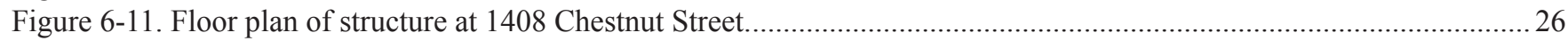

Figure 6-12. Historic makeshift repair work on 1408 Chestnut structure's interior walls. ....................................................26

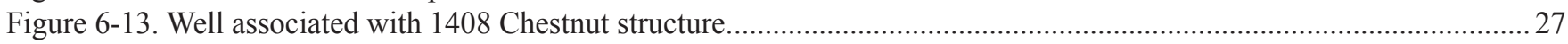

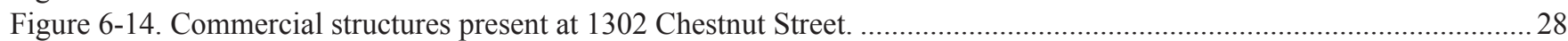

Figure 6-15. Farmer's Market pavilion structures at 1308 Chestnut Street..........................................................................28

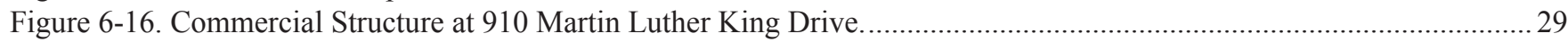

Figure 6-17. Foundation remnants of structure removed from 1404 Chestnut Street. ........................................................29

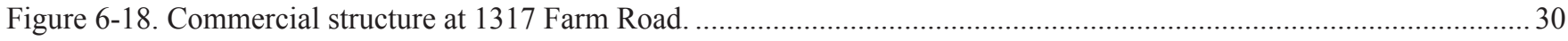

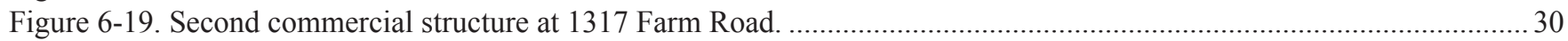

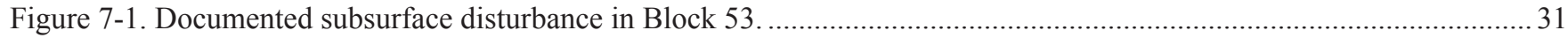




\section{Acknowledgements:}

A capable field-crew makes data collection from the archaeological record possible. The author wishes to thank Joseph Thompson and Cyndi Dickey for their diligent excavation efforts and paperwork assistance. Bruce K. Moses contributed greatly to the descriptive power of this report through the genesis of its graphics and maps. The archival skills of Kristi Ulrich, who came through in a pinch, were greatly appreciated. Dr. A. Joachim McGraw with the Texas Department of Transportation was able to provide very specific and difficult to obtain historic maps related to the project area. Gratitude is expressed to the City of Bastrop, Office of the City Manager, and to Gene Kruppa, with Befco Engineering, Inc., for coordination efforts. Lynn Williams, with the Bastrop County Clerk's Office, was a tremendous help with the location of various land deed records that can prove quite elusive when tracing properties back to the 1800s. Tom Wilson, a Development Specialist with 9-1-1 Addressing, contributed important property data on the project area. The author would also like to thank Beatrice Dodge, a conservation specialist associated with the Bastrop County Historical Society Museum, who was able to provide additional literature on the culture history of Bastrop. Theresa de la Garza Carwise provided services as Architectural Historian, bringing her much welcomed experience to the table. Marybeth Tomka's curational work with the collected cultural materials recovered during this survey is much appreciated. Finally, the Principal Investigator, Cynthia M. Munoz, and the Director of the Center for Archaeological Research, Dr. Steve A. Tomka, both provided valuable editorial input that significantly contributed to the clarity of this report. 


\section{Chapter 1: Introduction}

Under contract with the City of Bastrop, Office of the City Manager, the Center for Archaeological Research at The University of Texas at San Antonio conducted an intensive archaeological pedestrian survey of the proposed Bastrop Convention Center and City Hall project area (Figure 1-1) in April of 2008. Investigational methods consisting of reconnaissance walk-over survey, systematic shovel testing, and backhoe trenching were carried out on building Blocks
52, 53, 69, and 70, east of Fayette Street (Figure 1-2). The survey of the Area of Potential Effect (APE) was performed under Texas Antiquities Permit No. 4867 with Cynthia M. Munoz serving as Principle Investigator. The archaeological services that the CAR has provided are designed for obtaining cultural resources clearance from the Archaeological and Architecture Divisions of the Texas Historical Commission (THC), the State oversight agency. The Antiquities Code of

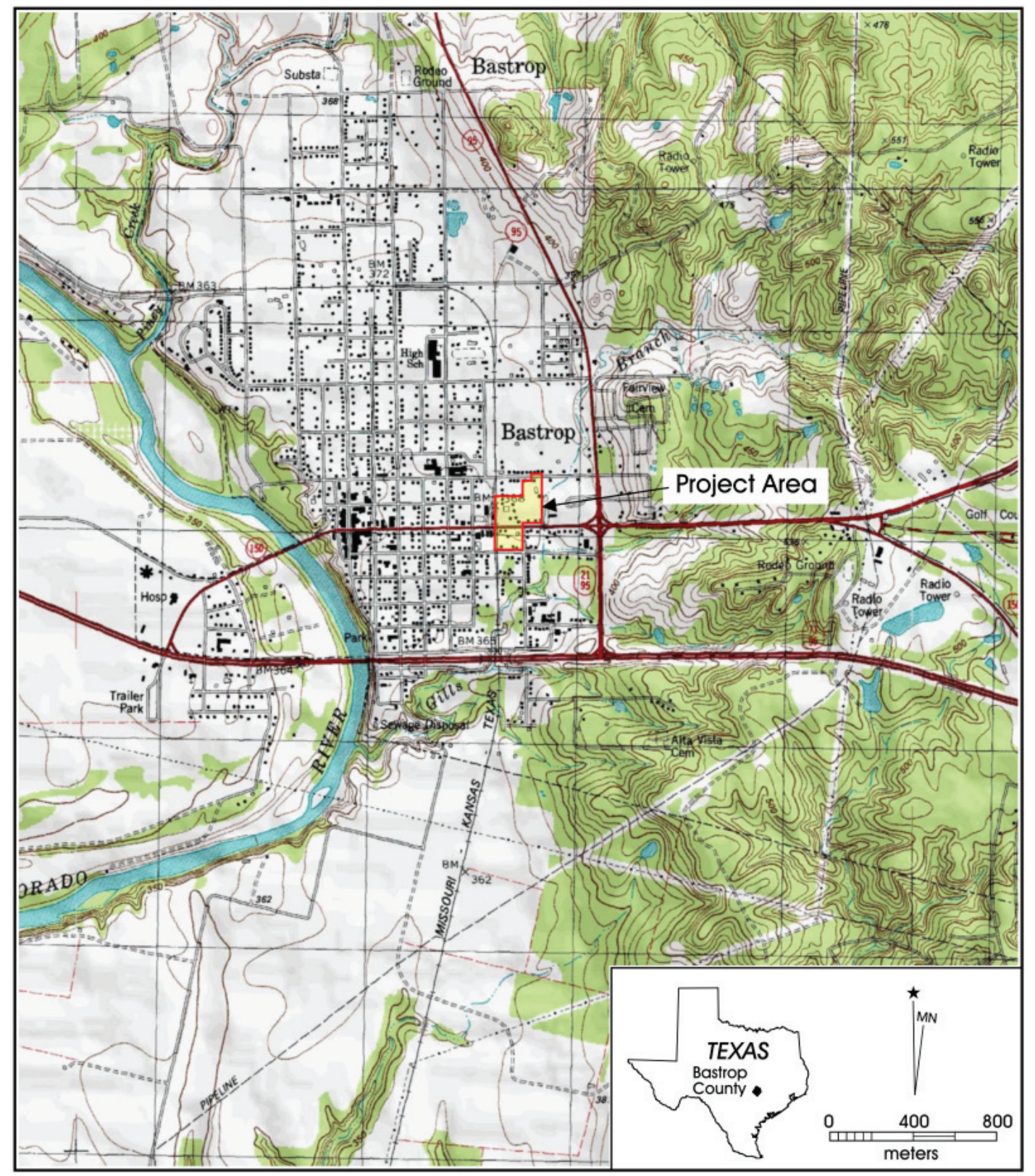

Figure 1-1. Area of Potential Effect in downtown Bastrop. 


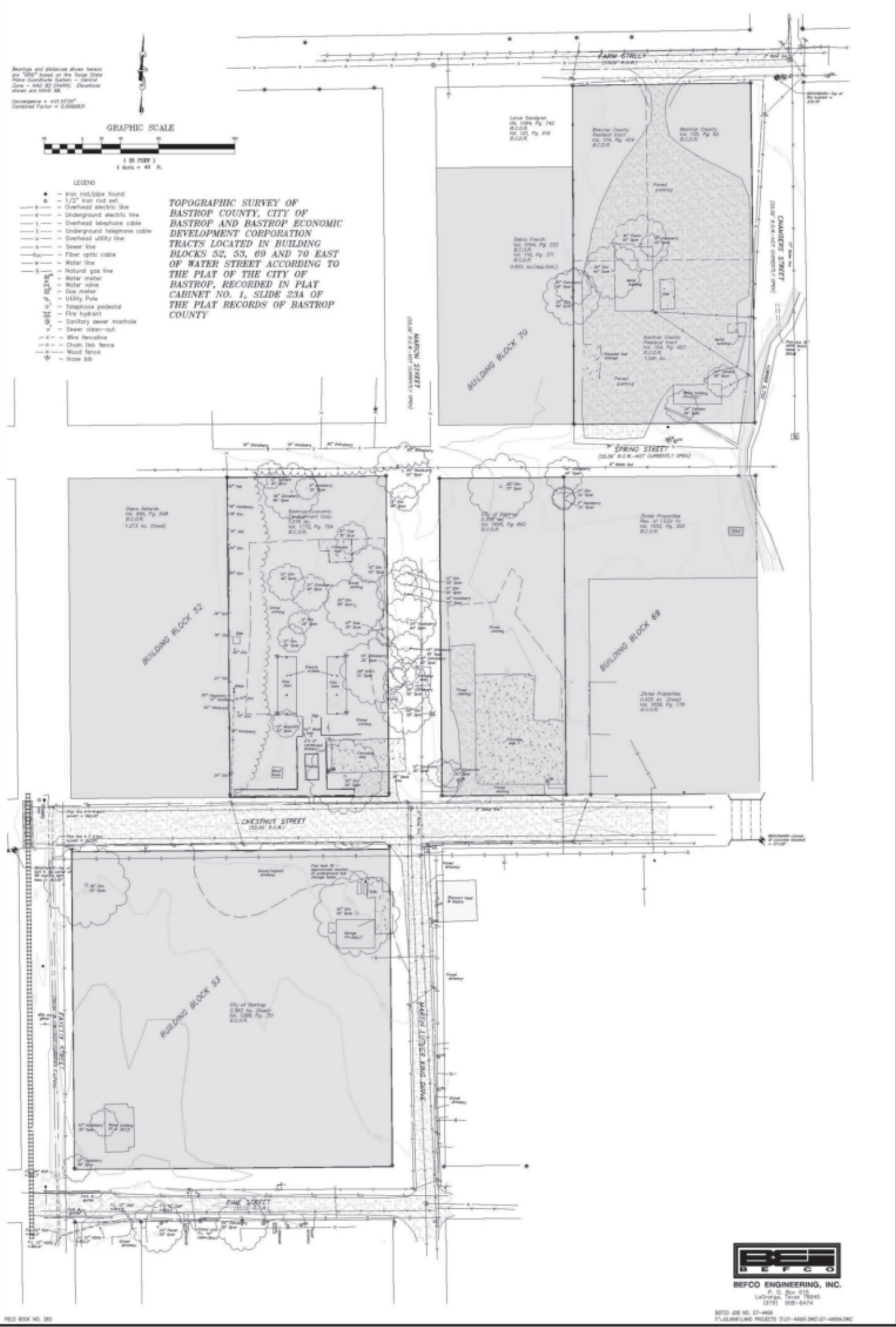

Figure 1-2. APE Blocks 52, 53, 69 and 70. 
Texas requires that any legal construction within lands owned by the State of Texas or one of its political subdivisions be preceded by an archaeological survey to establish whether any significant cultural resources may be impacted by the construction.

The principle objective of the pedestrian survey was to determine the possible presence of undocumented historic resources and prehistoric cultural deposits that could be impacted by the construction of the Bastrop Convention Center and City Hall within the project APE. The CAR of UTSA previously generated a desk-top review of the cultural resources that may be impacted by the proposed project and submitted this report to the THC for evaluation. After review, the Architecture Division concurred with the CAR's recommendation for the implementation of this pedestrian survey of the APE, and indicated no concerns with the visual impact of the project on nearby National Register of Historic Places (NRHP) listed properties that contribute to the rich cultural ambience of Bastrop's Historical District.

Archaeological survey work carried out by the CAR revealed a small historic site 41BP837 in the western half of Block 53 adjacent to the railroad. Additionally, an existing structure, 41BP839, within the southwest quadrant of Block 53 was found to be historic. A second structure, also historic, was documented in the southeast corner of Block 69. The remainder of the project area was systematically examined, and no other significant cultural features or deposits were encountered.

\section{The Project Area}

The area targeted for the Bastrop Convention Center and City Hall project is located in an urban setting within the central business district of Bastrop, Texas. It covers approximately four city blocks that are staggered between Farm Street in the north and Pine Street in the south. Fayette Street and the railroad serve as the western boundary for Blocks 52 and 53, with the closed off Marion Street as the western boundary for building Block 70. A small rectangular enclave within building Block 70 in the northwest corner, measuring roughly 40 by 60 feet, has been excluded from the project area. The eastern boundary of the APE is a closed off section of Chambers Street, that runs into Gills Branch, east of Blocks 69 and 70. The eastern boundary of Block 53 is Martin Luther King Drive. The northern boundary of the project area is Farm Street, north of Block 70, and a closed off section of Spring Street, north of Block 52. The southern boundary of the APE is Pine Street, south of Block 53, and Chestnut Street, south of Block 69.

The project area, part of the downtown Historic District of Bastrop (THC 2008), sits on a terrace above the Colorado River that flows roughly one mile away. Gills Branch receives most of the rainfall runoff. The Historic District rests above the 100-year floodplain. Gills Branch is in good hydrologic condition and is fairly stable. It currently contains some construction debris, but its banks are well vegetated and it is relatively obstacle free, facilitating sediment transport in the channel. Elevation is roughly $366 \mathrm{ft}$ amsl. Blocks 52, 53, 69 and 70 are covered primarily in Elm, Hackberry, Chinaberry, Sycamore, Magnolia, and Pecan trees, as well as native grasses.

The surface geology of the project area is composed of Eocene-aged Claiborne Group Limestones (Renfro 1979). This area falls within the Oak-Hickory to Pine Forest vegetative region of the Central Texas geographical region (Biesaart et al. 1985). Soils within the project area consist of light reddish-brown to brown sands overlying clay loams (Godfrey et al. 1973). They are mapped as Smithville Fine Sandy Loam and Sayers Fine Sandy Loam (Baker 1979). 



\section{Chapter 2: Cultural Background and Previous Investigations}

The term "prehistoric" pertains to temporal sequences that span over 10,000 years falling prior to A.D. 1550 , for which no written historic records exist. Once the prehistoric culture chronology for this region of Texas has been reviewed, a brief summary of prehistoric archaeological sites in the vicinity of the project area will be provided.

\section{Paleoindian}

The earliest evidence of humans in the Central Texas region occurred during the Paleoindian period which dates from 11,500-8800 BP (Collins 1995). As the Pleistocene ended, diagnostic Paleoindian materials in the form of Clovis, Folsom, and Plainview projectile points began to enter the archaeological record. These points were lanceolate-shaped and fluted for hafting to wooden spears. Using the launching momentum from atlatls (spearthrowers), large game such as mammoth, mastodons, bison, camel, and horse were frequently taken (Black 1989). Stylistic changes in projectile point technology occurred during this later portion of the period, eventually shifting to Dalton, Scottsbluff, and Golondrina traditions. While widespread in geographic range, these types occurred in high densities in the High Plains and Central Texas (Meltzer and Bever 1995). In addition to megafauna, it is likely that Paleoindians took less daunting prey as well, such as frogs, turtles, and antelope. When megafauna eventually died off and the climate warmed, subsistence patterns shifted toward smaller game and plant foraging.

\section{Archaic}

The Archaic period, broadly divided into the Early, Middle, and Late Archaic sub-periods, signifies a more intensive reliance on local floral and faunal resources with an increase in the number of projectile point styles (Collins 1995). The archaeological record begins to indicate more widespread use of burned rock middens, a wider variety of site functions, and more localized geographic distributions of these materials.

\section{Early Archaic}

Hester places the Early Archaic between 7950 and 4450 BP based on the occurrence of Early Corner Notched and Early Basal Notched projectile points (1995:436-438). Collins' dating of the Early Archaic sub-period to 8800 to 6000 BP is centered on the occurrence of unstemmed point types that were previously considered Paleoindian in age (1995:383).
Around 8000 BP projectile point hafting styles transitioned to stemmed varieties such as the Martindale and Uvalde (Black 1989). As the extinction of megafauna herds took hold, a subsistence shift towards heavier reliance on deer, fish, and plants became necessary. In the archaeological record, this trend equates to greater densities of ground stone artifacts, fire-cracked rock midden features, and task-specific tools. A number of Early Archaic open-air campsites have been investigated along the eastern and southern margins of the Edwards Plateau in areas with reliable water sources (McKinney 1981). Population densities were relatively low and consisted of small bands with a fairly high degree of mobility (Story 1985:39). Loeve-Fox, Jetta Court and Sleeper sites are representative of Early Archaic sites (Collins 1995).

\section{Middle Archaic}

Middle Archaic materials date from about 6000 to 4000 BP. The sub-period is characterized by the increased occurrence of multi-use bifacial knives and burned rock middens (Collins 1995:383). Diagnostic points from this sub-period include Bell, Andice, Taylor, Nolan, and Travis. The first two types are considered as Early Archaic by Hester (1995). Although bison may still have been hunted in the state during the beginning of the Middle Archaic, the climate became much drier towards the end of the Middle Archaic necessitating a heavier reliance on sotol and acorn harvesting (Weir 1976:126). An expansion of oak woodlands on the Edwards Plateau and Balcones Escarpment may have been conducive to the intensified exploitation of certain plants (Weir 1976). This sub-period also experienced population increases and it is possible that previously scattered bands of huntergatherers began to combine harvesting and processing efforts (Weir 1976:126). Panthers Spring, Landslide, Wounded Eye and Gibson sites demonstrate well the cultural trends of the Middle Archaic (Black and McGraw 1985; Collins 1995).

\section{Late Archaic}

The last subperiod of the Archaic falls between 4000-800 BP (Collins 1995:384). Dart point diagnostics of the Late Archaic include somewhat smaller, triangular dart points with corner notches such as the Ensor and Ellis (Turner and Hester 1993:114,122). Late Archaic points also include Bulverde, Pedernales, Marshall, and Marcos (Collins 1995). It is not entirely clear whether this sub-period experienced a rise (Collins 1995, Prewitt 1981) or decline (Black 1989) in population numbers, but large cemeteries, grave goods, and 
exotic trade items are known to occur at this time at sites such as Loma Sandia, Rudy Haiduk, Silo, Ernest Witte, and Morhiss Mound in Central and South Texas. Evidence from these and other cemetery sites (i.e. Thunder Valley sinkhole cemetery) suggest the emergence of territoriality during the Late Archaic, possibly as a result of population increase (Bement 1989). The frequency of burned rock middens and open campsites appears to increase. The Anthon and Loeve Fox sites are characteristic of the Late Archaic sub-period (Collins 1995).

\section{Late Prehistoric}

Some degree of overlap exists between diagnostic tools that are considered Late Archaic and Late Prehistoric, but the commonly held date for the beginning of this period is 1200 BP. A hallmark transition for this period is the introduction of the bow and arrow that enabled prehistoric hunters to harvest prey from greater distances with less need for the brushless, wide open spaces required for atlatl maneuverability in hunting. The use of arrows is indicated by much smaller sized projectile points like the Perdiz and Scallorn forms. Another turning point in the Late Prehistoric period is the first substantial presence of pottery in the northern South Texas Plain and Central Texas (Black 1989; Story 1985). Researchers generally agree that during this period there was a drop in population (Black 1989). Inter-group conflicts between various bands of hunter gatherers may have also been an issue based on evidence of arrow inflicted deaths seen in human remains from various Late Prehistoric cemeteries. Sites with distinct Late Prehistoric components include the Kyle, Smith and Currie sites (Collins 1995). The Late Prehistoric period is divided into the Austin and Toyah phases. Johnson (1994) believes these phases to possibly be two distinct cultures (see Black and Creel 1997).
The Austin Phase of the Late Prehistoric may represent the most intensive use of burned rock middens (Black and Creel 1997), and includes diagnostic arrow point types including Scallorn and Edwards (Collins 1995; Turner and Hester 1993). During this phase, the use of burned rock middens was quite widespread. The Toyah Phase of the Late Prehistoric suggests interaction between Central Texas and ceramic producing traditions in East and North Texas due to the presence of bone-tempered plainware ceramics commonly referred to as Leon Plain in Toyah components (Pertulla et al. 1995). Ceramics commonly used in East Texas by 2450 BP, but the first Central Texas plainwares did not appear until ca. 650/700 BP. Other technological traits of this phase include the diagnostic Perdiz arrow point, alternately beveled bifaces, and specialized processing kits as an adaptation to flourishing bison populations (Ricklis 1992) or an adaptation to intensification of bison procurement.

\section{Prehistoric Sites in the Proximity of the Project Area}

Numerous archaeological undertakings have been carried out in Bastrop County in the last five years alone (Nickels et al. 2003; Moses 2004; Godwin 2005; Godwin and Clark 2005; Driver 2006; Figueroa 2006; Lohse and Bousman 2006; Munoz 2006). The following archaeological sites to be briefly discussed are all within one kilometer of the APE and are listed on the Texas Archaeological Site Atlas. 41BP80 is a prehistoric occupation site that yielded a small number of mussel shell fragments, lithic debitage and a small number of burned rocks. It is located northeast of the project area. Site 41BP87 is located northwest of the project area. It is described as a shallow lithic debris scatter in the southeast corner of an athletic field. 41BP80 and 41BP87 were both recorded by John W. Clark (THC 2008). There is also a site registered as 41BP65 in this area, but no information exists on it. 


\title{
Chapter 3: Historic Resources of Bastrop County
}

\author{
Jon J. Dowling and Theresa de la Garza Carwise
}

\section{Culture History of Bastrop County}

Bastrop, Texas is one of the earliest settlements in Central Texas dating back to 1832 . Before this locality was known as Bastrop, it was settled briefly during the Spanish Colonial period, and eventually colonized by Stephen F. Austin as the center of his "Little Colony," founded in 1830. Pivotal to the early colony's beginnings was the Spanish road network that ran through this area, known as the Camino Real (Figure 3-1).

Camino Real, meaning "Royal Highway" in Spanish, often referred to as the "King's Highway", is the oldest road network in Texas that began as a series of Indian trails (THO 2007). The Spanish eventually improved and expanded them to link a series of fortified missions, connecting settlements in Mexico to colonies in Louisiana via the Texas hinterland (see Figure 3-1). The Camino Real ran from Monclova, Mexico to Robline, Louisiana. The Texas segment consists of roughly 540 miles, with 47 miles of road in Louisiana. Portions of it were also known as The Old San Antonio Road, the King's Highway, and the San AntonioNacogdoches Road.

The Camino Real's European expansion beyond an Indian trail started with provisional Governor Domingo Teran de los Rios' expedition in 1691, cutting a course from Monclova, Mexico, to the Spanish missions in East Texas (THC 2008). It was more than a route; it was a "complex set of relationships between travelers and nature, buyers and sellers, governors and governed", where the threat of Indian attack, transportation impediments, and subsistence procurement were constant obstacles (de la Teja 1998:43). Proceeding east from San Juan Bautista (Presidio del Rio Grande), an expedition gateway of sorts on the Rio Grande River, the Camino Real eventually crossed the Colorado River into present day Bastrop County, before making its way to the end of the line in Robline, Louisiana and Los Adaes, Louisiana (Figure 3-1). One segment of the Camino Real, called the Camino Arriba, was subjected to greater traffic from East Texas travelers headed to the West Coast during the Gold Rush in the 1940s. During the American Civil War, it served as an important trade artery for transportation of cotton from East Texas to Mexico. Throughout Texas history, depending on transport mode, season, and route choice, the Camino Real was utilized for a variety of reasons including commerce, transportation, communication, and military campaigning (McGraw et al. 1998). The junction at the Colorado River, however, was a particularly important one and served as a catalyst to continuous growth and settlement, giving rise to Bastrop County's first major settlement in 1805, a stockade known as Puesto del Colorado (Post on the Colorado, Kesselus 1986:26-27). Bastrop remains one of only four permanent Texas settlements with roots grounded in Mexican rule.

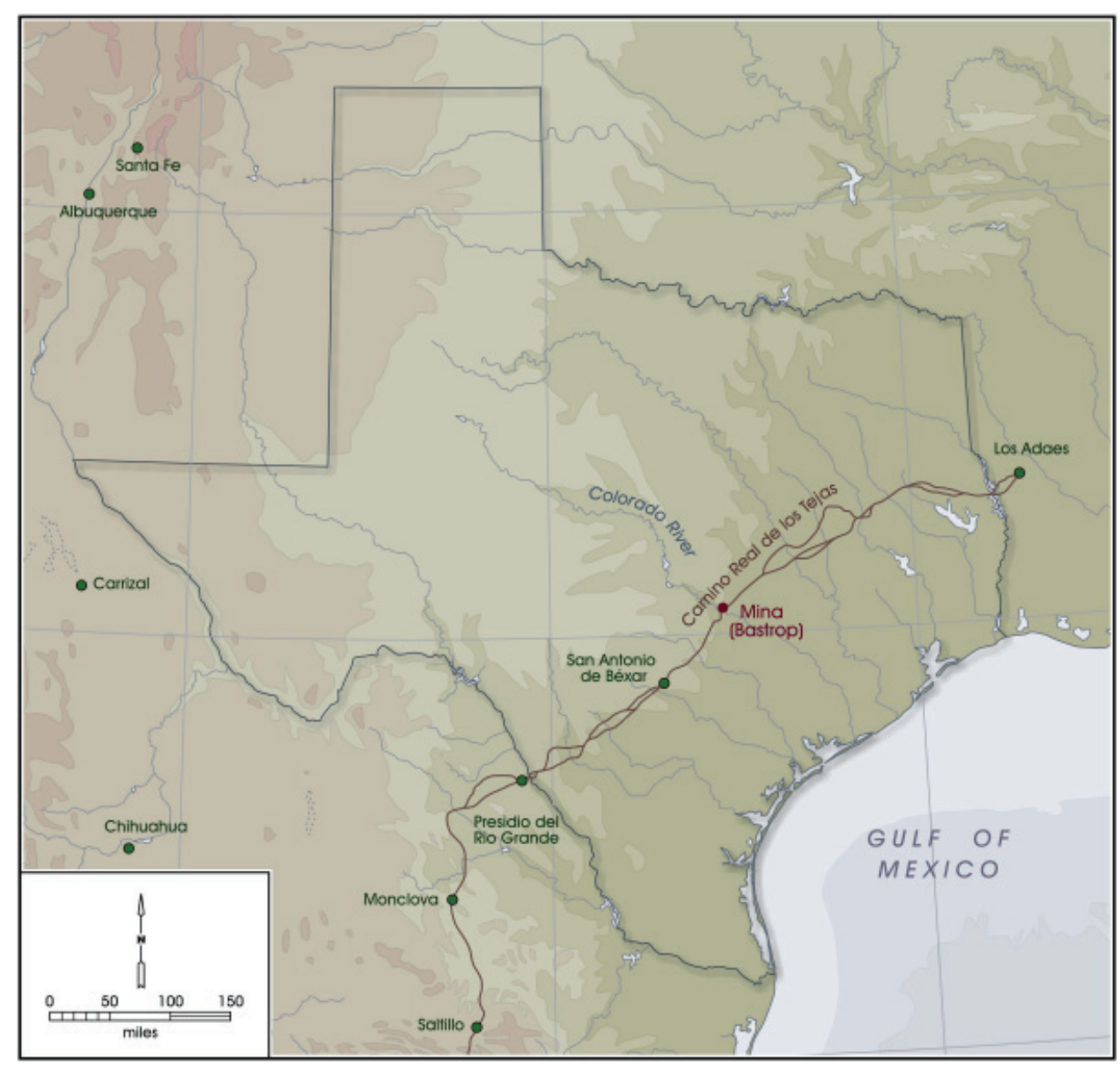

Figure 3-1. Camino Real in relation to Mina (Bastrop). 
After the second Mexican Revolution of 1821, Stephen F. Austin soon began to focus Anglo settlement efforts in the area around Puesta del Colorado, establishing his permanent colony that he named Mina, after a tragically fated Mexican hero. Mina was designated as four square leagues for a geometric town tract with streets running in the cardinal directions with a town square at its nucleus (THC 2008). The west block of town was designated for municipal buildings, the east for church functions, the north for the jail and the south and southwest served as educational districts. The cemetery was placed in the northeast. This design maintains little prevalence today. In the $1830 \mathrm{~s}$, growing numbers of Anglo/Celts began to settle in this area receiving large land grants, contributing to the prominent Anglo population.

In answer to the suppression of Texas settlers by Antonio Lopez de Santa Anna and his blatant disregard of the Federalist Constitution of 1824, Mexican forces were expelled from Texas in the Battle of Bexar in December of 1835. Santa Anna's immense army quickly remobilized, and marched into the recalcitrant province of Texas the following month in January of 1836, beginning a series of conflicts on Texas soil. Texans suffered crushing defeats in Goliad and at the Battle of the Alamo in San Antonio de Bexar. Colonel William B. Travis's predecessor, Colonel James Clinton Neill, was en route to Mina after he turned over command of the Alamo to Colonel Travis. To escape the imminent arrival of Santa Anna's army, citizens of Mina fled the town during the "runaway scrape". Mina sustained several fires started by Mexican soldiers under the command of General Gaona. After the Texas victory over Santa Anna at the Battle of San Jacinto, the Republic of Texas was created and citizens of Mina returned to their lands only to face another increasing threat, Indian raids.

Indian attacks reached their peak during and immediately after the Texas Revolution (THC 2008). Fort Colorado, upriver from Mina, offered some protection from Comanche bands, but eventually a local company of rangers was organized to lessen the severity of Indian raiding. Local rangers, paid with public funds, were later assisted with government paid Texas Rangers to secure the area from attack.

With the founding of the new Republic of Texas in 1837, the Mexican municipality of Mina was renamed the county of Bastrop, one of twenty-three counties of the Republic of Texas. It was named after Felipe Enrique Neri, Baron of Bastrop, a pivotal figure in the settlement of Anglo Americans in Texas. Bastrop and Waterloo were both considered as the location for the capital of Texas. Waterloo, later named Austin, was chosen.
In 1845 Texas was admitted into the United States as the fortyfirst state. Texas eventually became a Confederate state voting for secession from the Union. Bastrop County supported the decision, although some settlers were supportive of abolition, but not war. Texas contributed more soldiers per capita than any other Confederate state with the exception of Alabama (THC 2008). Only five major engagements were fought on Texas soil. Two were fought in Sabine Pass, two occurred in Galveston, and one engagement was fought in Palmetto Ranch. Each of these locations involved major ports or entry areas into the state. Following Reconstruction in the 1870s, the economic and political situation in Texas began to gradually improve. Ever-increasing traffic from stagecoaches, river ferries, and the railroad increased the transport of goods and travelers, establishing Bastrop as a desirable transition stop along the Camino Real.

The railroad in particular stimulated Bastrop's economic growth considerably before many other Texas counties were able to reap the rewards of the transportation marvel. The Houston and Texas Central Railroad, formed in the early 1860 s, included a stop in Bastrop County as early as September of 1871. It eventually hooked up with the Colorado and Post Oak Island Railway (THC 2007; Moore 1977:94). To facilitate transport to the north, Bastrop citizens attempted to build a railroad line to the town of Taylor. They formed the short-lived stock company Taylor, Elgin, and Bastrop Railway Company that eventually led to the construction of the Missouri, Kansas and Texas (MKT) Railway Company in June of 1887 (Moore 1977:95). The MKT Railway Company finally connected to Houston on April 10, 1893, and runs were made for over one hundred years until MKT operations ceased in 1989. The railroad aggrandized trades such as oilwell supply and drilling, timber milling, coal mining, and iron manufacture. Parts for cotton gins and plows arrived that could handle the compact Blackland Prairie soils in certain farmsteads, leading to an explosion in cotton cultivation in Bastrop County, ultimately contributing to a prominent tenant farm culture that persisted into the 1930s. During the Depression era, however, an additional transportation marvel was becoming firmly implanted in Bastrop culture. By 1935, the covered wagon and the buggy were no longer advertised in the Bastrop newspaper, and "the Big 80 horsepower kneeaction Chevrolet" soon led to the demise of local livery stables (Sumerlin 1963:14). The railroad and the automobile soon became the transportation norm.

In deference to Bastrop's standing historical resources, it is important to address the influence of Victorian era architecture on Central Texas after Reconstruction. Technological advancements and the growing importance of the railroad meant that builders could utilize more than just local materials and take advantage of precut factory- 
made metal building hardware. The Victorian style grew in popularity, drawing heavily from many revival styles such as Gothic Revival, Italianate, Second Empire, Queen Anne and Richardsonian Romanesque (HTO 2008). Texas was catching up with American mainstream architectural fashion. Both residential and civic commercial architecture took advantage of asymmetrical planning styles, using eclectic materials and designs, typical of the revolutionary changes engendered by the Victorian style. These expressions included styles rich in ornate details, intended to achieve romantic and picturesque effects. Buildings were typically asymmetrical and characterized by off-center roof features and projecting bays and windows, spindlework, dormers, punch work, chimneys, decorative glass, and shingle patterns (HTO 2008). The final composition was intended to appear well balanced and picturesque, with the exception of Folk Victorian homes where decorative features were limited to the façade (McAlester 1984).

\section{Documented Historic Resources in the Proximity of the Project Area}

Documented Resources to be reviewed fall under three categories: National Register of Historic Places (NRHP), Neighborhood Survey (NS) listings, and previously documented archaeological sites. Not all recorded resources are still present, and some resources within, and around the Bastrop Convention Center and City Hall project area, have not yet been evaluated for eligibility to the NRHP. Using data from the Texas Historical Commission Site Atlas, this section reviews all relevant cultural resources associated with, or in close proximity to, downtown Blocks 52, 53, 69 and 70 (Figure 3-2).

The following properties were included in the neighborhood survey and listed on the National Register of Historic Places.

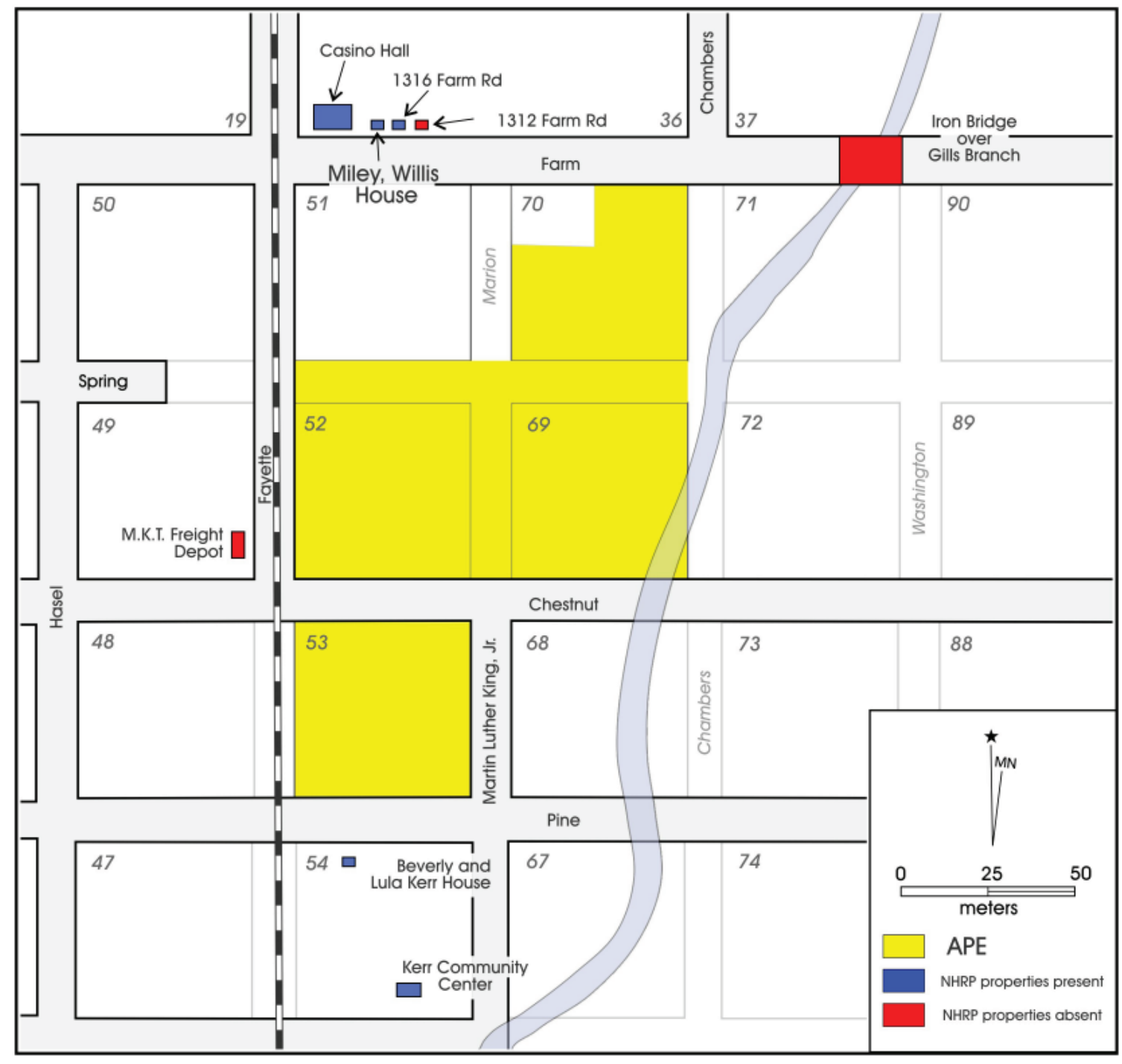

Figure 3-2. NRHP cultural resources associated with the APE. 
These properties are found in the immediate vicinity of the four blocks that comprise the project area. The first property to be discussed is Bastrop's Iron Bridge over Gills Branch. It was formerly situated just west of the Farm Road and Highway 95 intersection. The bridge rested over Gills Branch, but it is listed in the NRHP as resting over Piney Creek, an alternate nomenclature. This iron-truss bridge was the first permanent bridge to be built in Bastrop County, and was erected in 1881 for a cost of $\$ 1,400.00$ (Moore 1977:93). It was designed by the MO. Valley Bridge \& Ironworks Company (THC 2008). It is unclear when this bridge was removed and replaced with a modern concrete bridge (Figure 3-3), but some bricks that may have been part of its foundation, along with numerous other construction debris, still lie within the bed of Gills Branch.

The Miley, Willis House, located at 1320 Farm Road, maintains much of its architectural integrity (Figure 3-4). Its architectural style suggests it dates from around the $1870 \mathrm{~s}$ to the turn of the nineteenth century (THC 2008). The single-level dwelling was constructed in the Folk Victorian style. The woodframe sits on brick piers (THC 2008). The home's gable-front and wing design was common in post-railroad America (McAlester 1984). Victorian detailing includes small eave brackets and semiturned columns. Façade fenestrations include two vertical $2 / 2$ windows on the pedimented gable end and along the wing. Typical of Folk Victorian homes, the fenestrations are symmetrical with a central entry wrapped by a transom and side-lights. The exterior walls are clad in horizontal wood siding. Contemporary features include gutters along the porch, embossed metal skirting around the base and a metal roof. This property appears to be well-maintained.

The NRHP listed residence at 1316 Farm Road is a single-level home and appears to be a simple, side-gabled, hall-andparlor plan with a rear extension, all typical features of the National Folk Style (Figure 3-5). As is common in the South, it also has the full-width, shed-roofed porch. Unlike the Miley, Willis house, this structure lacks the ornamentation to classify it as Victorian Folk, and lacks the features expected of Greek Revival, as classified in the NRHP listing. The symmetrical façade contains two adjacent central doors with a single/double-hung 12-light window at either end. The walls are covered in a horizontal siding. The lack of windowsurrounds indicates that the windows may be contemporary replacements or the house may be sheathed in modern building fabrics. The home appears to be well-maintained.

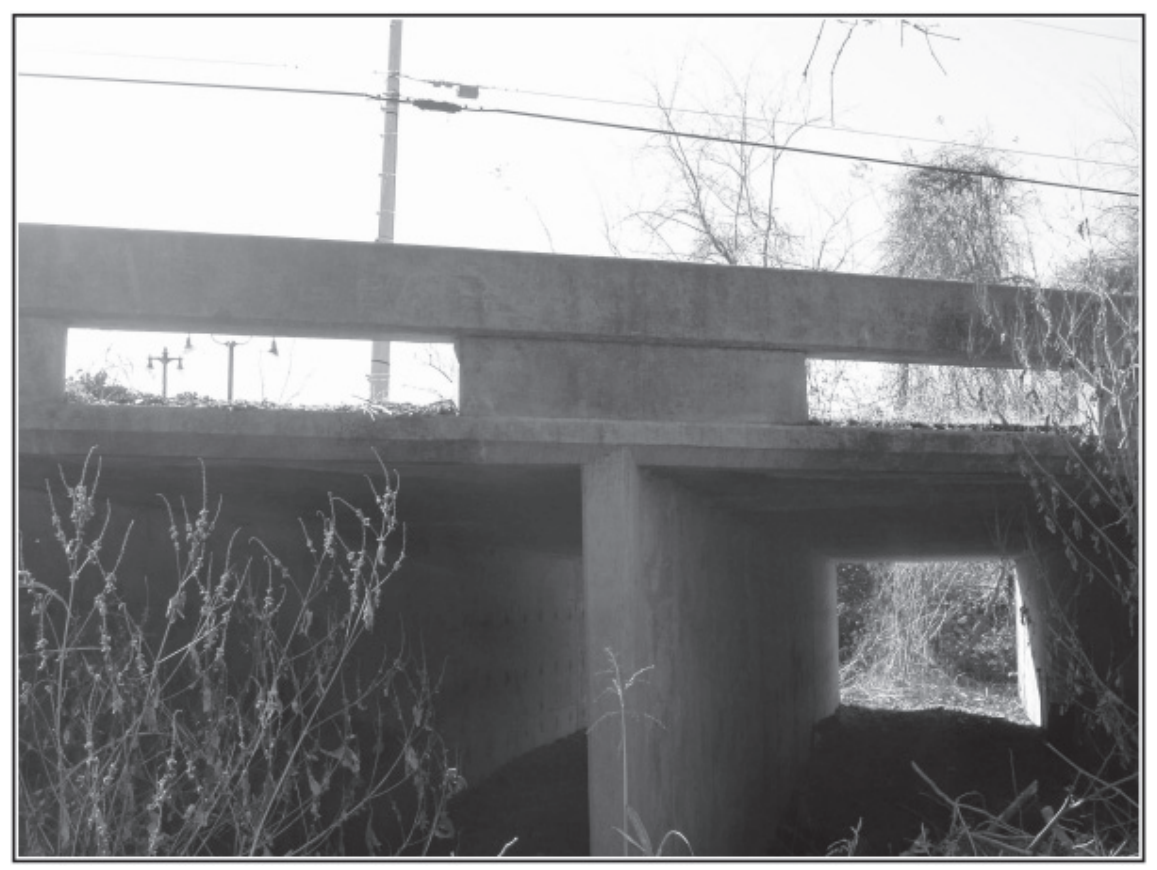

Figure 3-3. Current bridge over Gills Branch.

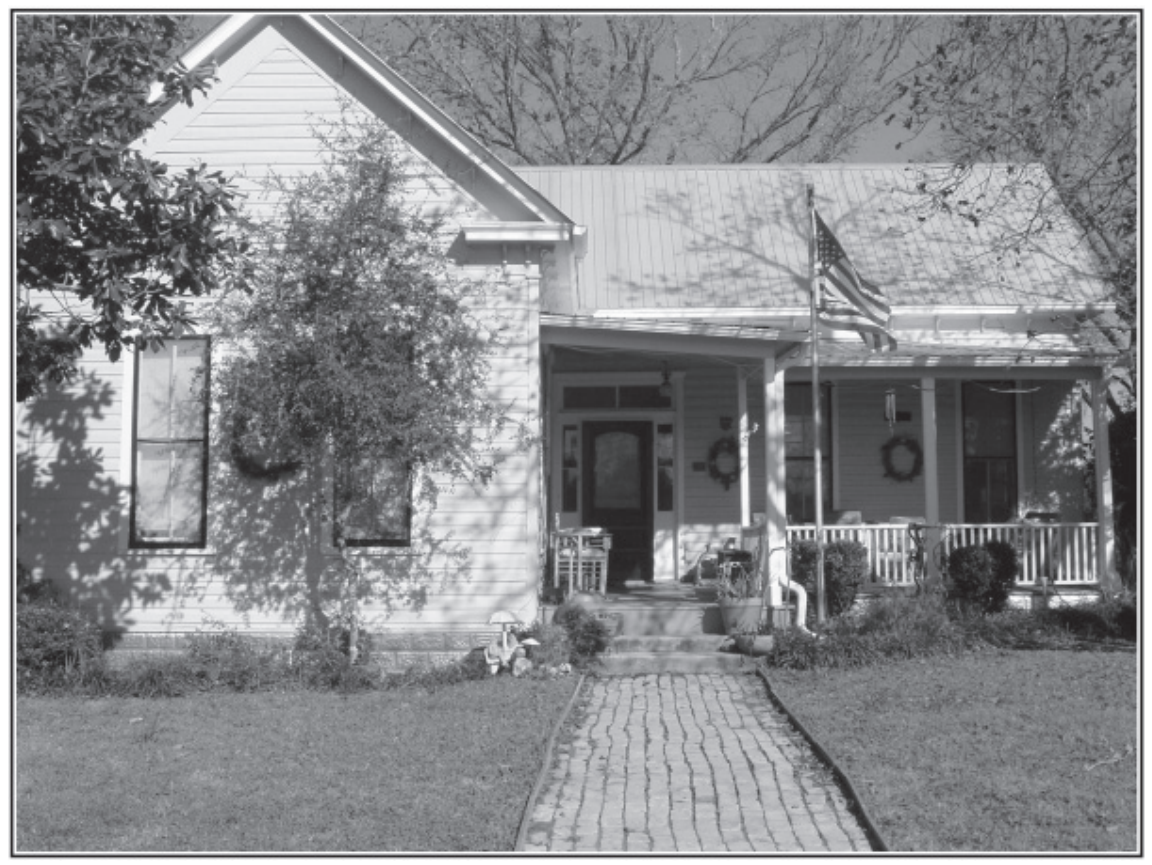

Figure 3-4. Miley, Willis House at 1320 Farm Road. 
A listing on the neighborhood survey of historic places that no longer stands is the residence at 1312 Farm Street. It was a Greek Revival Vernacular style dwelling (THC 2008). Nothing currently remains of the original structure and a modern structure now rests on the property.

The next property appears on the neighborhood survey of historic places, is listed on the NRHP, and is one of the county's oldest cultural centers. Designed by Alf Jung and constructed in 1848, the Casino Hall is situated on the Northeast corner of Farm and Fayette. The onestory brick building has a rectangular plan with gables at the short ends and a loading dock on the south side (Figure 3-6). Two ventilators sit along the roof ridge, and like the roof, are clad in corrugated metal. The structure is vacant and in poor condition with a severely corroded roof and structural deterioration evident in multiple areas. Masonry repairs are evident throughout the structure and wood features lack protective paint. Casino Hall is symbolic of the cultural improvement in Central Texas. By the late 1880s, Texas had joined the transcontinental theater circuit. Casino Hall also served as one of Bastrop's earliest schools.

At the northwest corner of Chestnut and Fayette, the M.K.T. Depot used to stand just west of the railroad tracks. The Missouri, Kansas, Texas Railroad line erected the structure in 1885 for storage purposes (THC 2008), and it remained in use for its original purpose into the 1980s. Nothing remains of its board and batten frame, but its original position can still be detected by comparing old photographs with still-standing landmark features (Figures 3-7 and 3-8).

The Beverly and Lula Kerr House has a long history. It is located at 1305 Pine Street. The domestic single dwelling was constructed in the 1890s, and was home to two music teachers who were prominent African American leaders in Bastrop County (THC 2008). The structure's steep hipped roof with a low cross gable and a wrap porch are stylistically Queen Ann Victorian (Figure 3-9). Supporting the porch's continuous roof are chamfered columns, typically found on Second Empire or Stick Victorian homes (McAlester and McAlester 1984). No Victorian adornment is visible upon the façade. The porch railing, transom door and windows are regular and simple. Corrugated metal covers the roof, with exterior walls and the pedimented gable end clad in horizontal siding. The main level of the home sits atop a basement, which is only partially below grade. The home appears to be in good condition.

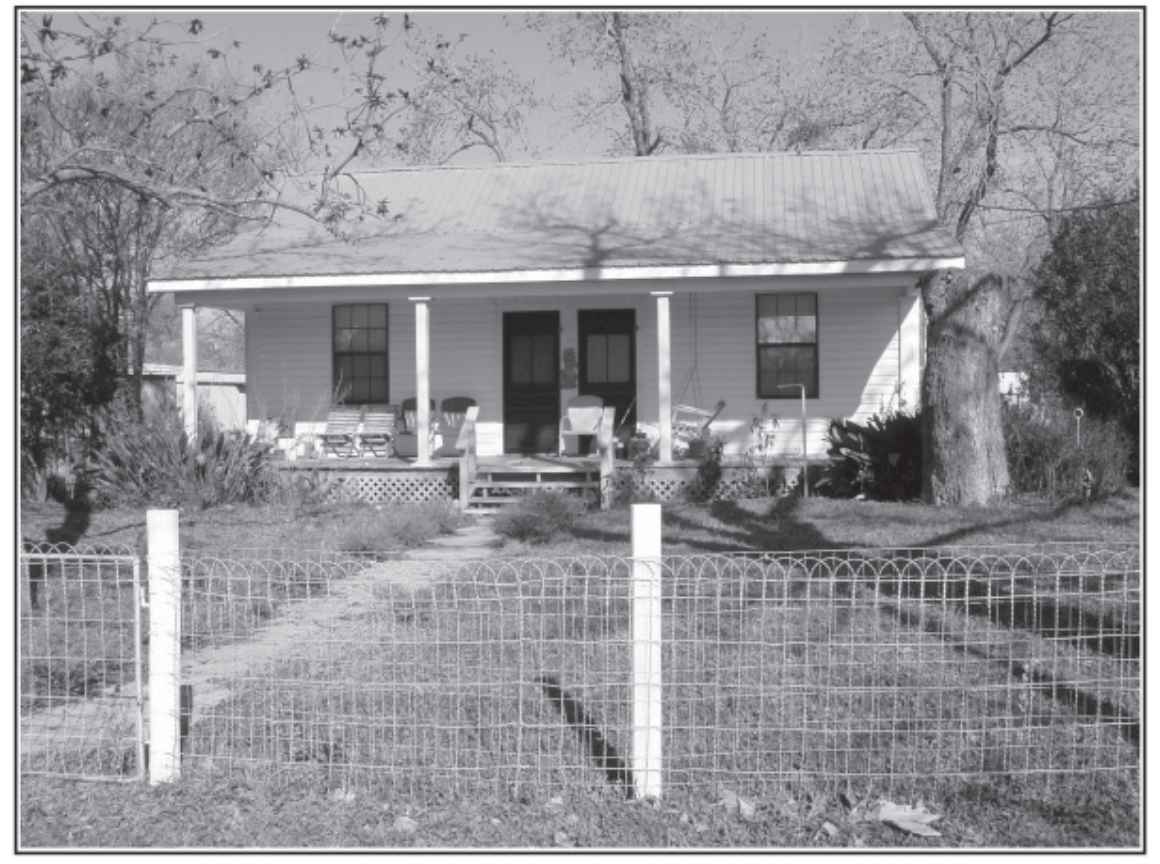

Figure 3-5. Residence at 1316 Farm Road

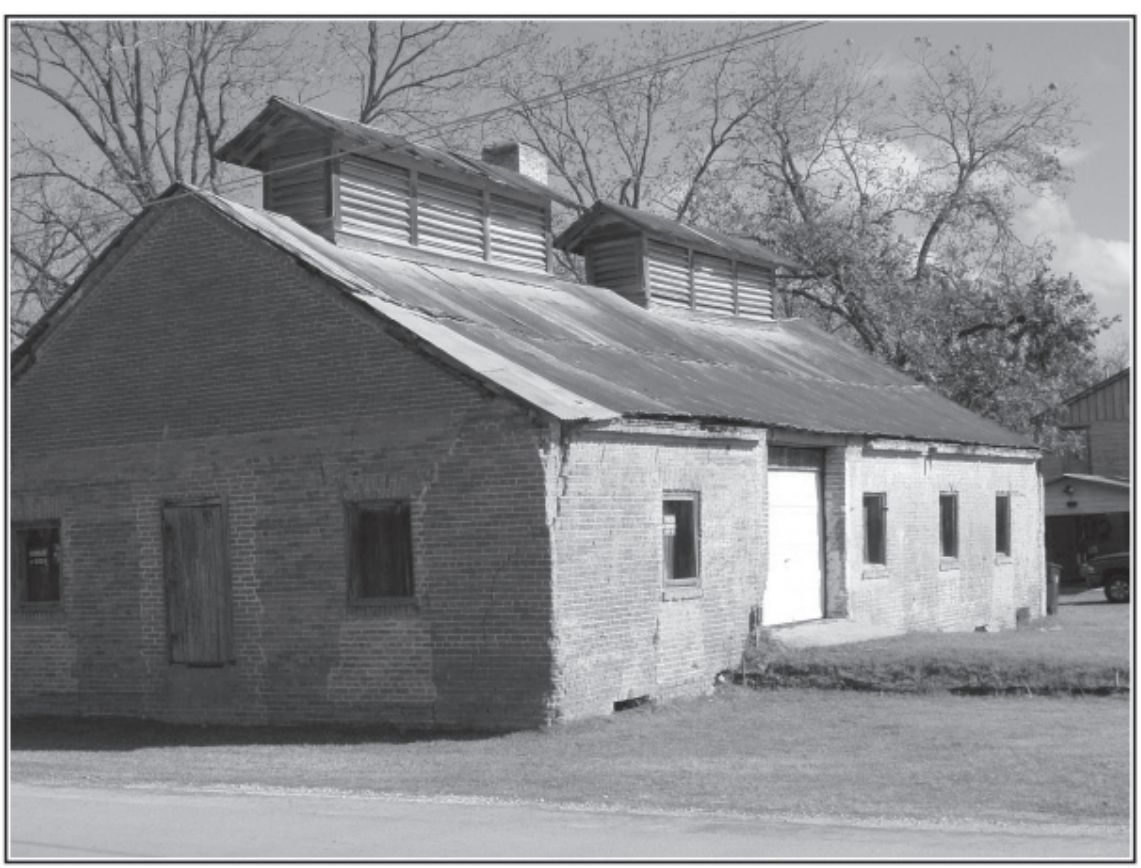

Figure 3-6. Casino Hall . 


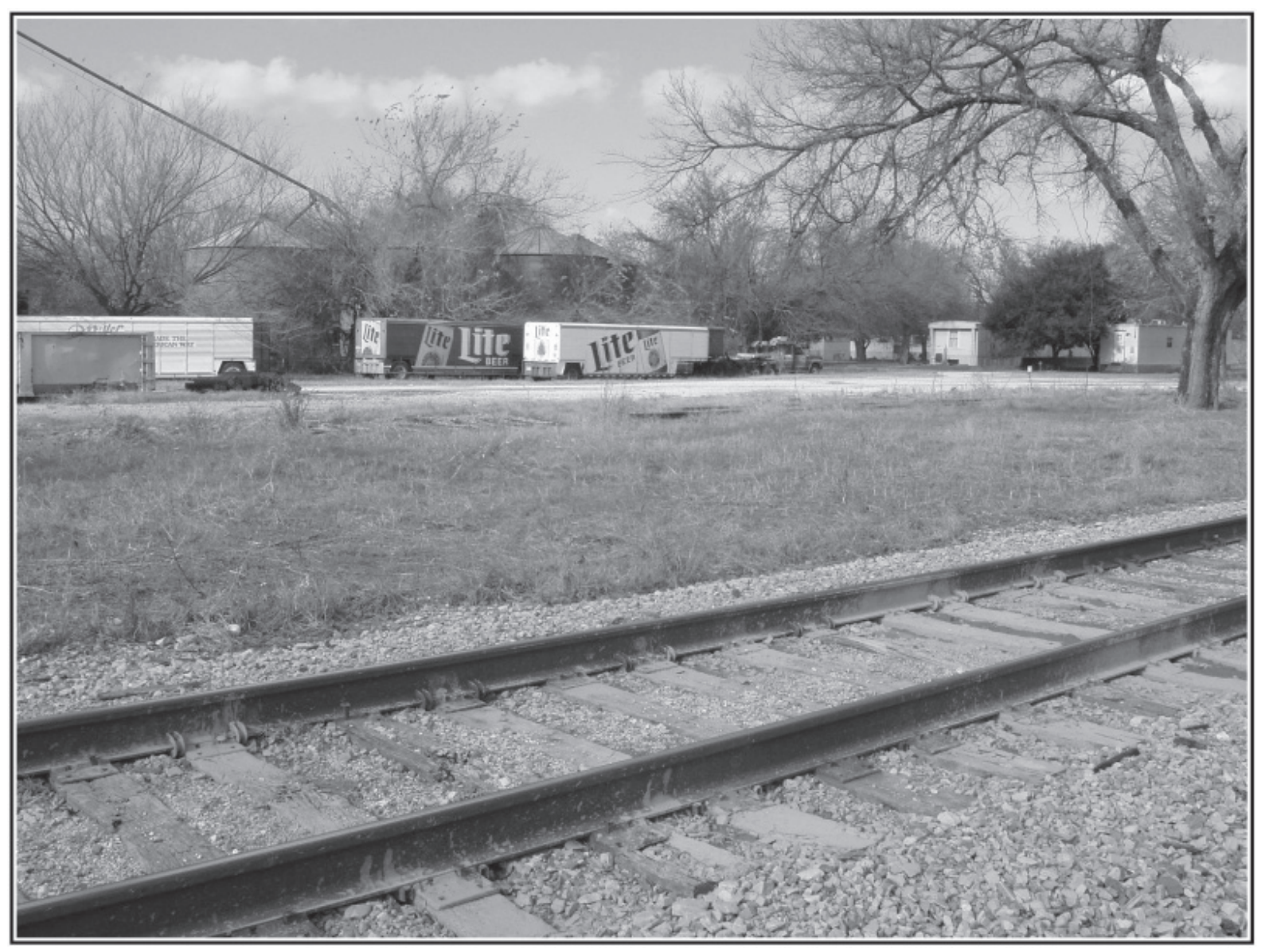

Figure 3-7. Former location of the M.K.T. Depot.

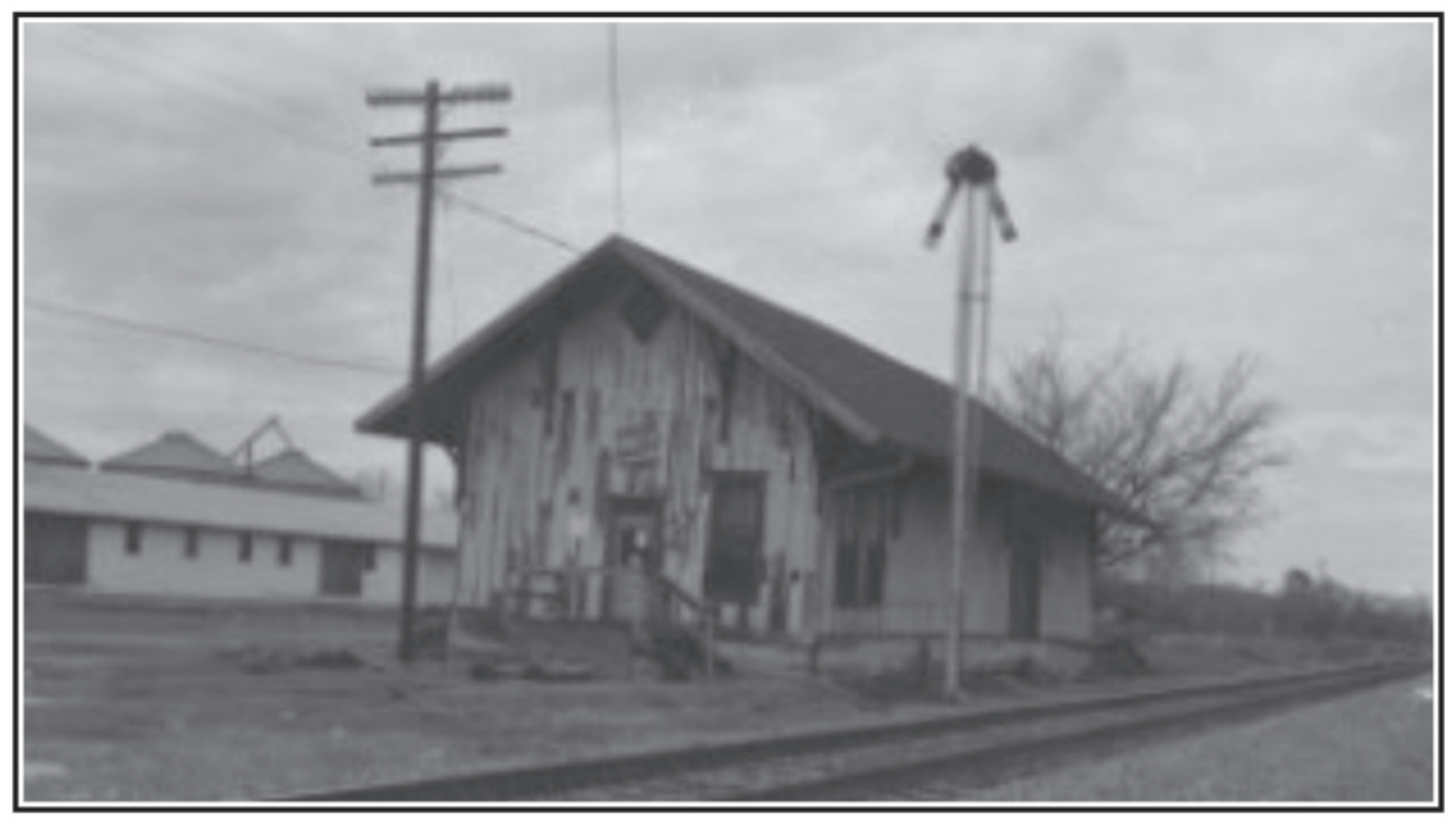

Figure 3-8. Old photograph of M.K.T. Depot with still standing landmarks in background. 
Recognizing a need for an African American activity and educational facility, the Kerr family saw to the construction of the Kerr Community Center and Park in 1914 (THC 2008). Numerous social events were held in the original Kerr's Hall, which has been beautifully restored as the Kerr Community Center (Figure 3-10). It has housed GIs, senior citizens, and mentally challenged people over the years, and hosted numerous community events as a testament to the good will of its founders. The symmetrical, twostory, side-gabled building has a first and smaller second floor with additions on the east end. The roofing material on the main structure and the additions consists of standing-seam sheet metal. Unlike the horizontal-sided main structure, the additions have board-and-batten siding.

The final NRHP property to be discussed is the residence at 1308 Fayette Street. This structure, listed as a Late Victorian domestic single dwelling does not stand at the location plotted by the Texas Site Atlas (THC 2008), shown to be within the APE. The actual location of 1308 Fayette Street is over 200 meters to the northwest of the project area, well outside of the APE. This NRHP property, is therefore, not considered to be in close association with the project area.

The following archaeological sites are all historic in nature, and are listed on the Texas Archaeological Site Atlas (Figure 3-11). Site 41BP687 is a twentieth century well associated with the above mentioned Kerr Community Center. This site has associated historic artifacts including whiteware ceramics and building materials with house mounds remnants, and was investigated by Antiquities Planning \& Consulting (Godwin 2005). The research potential of the artifacts appears to be limited, but the fact that the well is associated with an NRHP property makes it a significant historic property in its own right.

Site 41BP340 consists of the standing 1891 jailhouse and 1883 courthouse buildings, along with the twentieth century annexes to the courthouse. Archaeological deposits associated with the structures are highly disturbed due to the placement of a parking lot and various underground utilities. Architectural elements were recorded by the Texas Archaeological Research Laboratory (THC 2007). Site $41 \mathrm{BP} 79$ is a cemetery that occupies two large blocks near Gills Branch Creek. It contains a small number of early nineteenth century headstones.

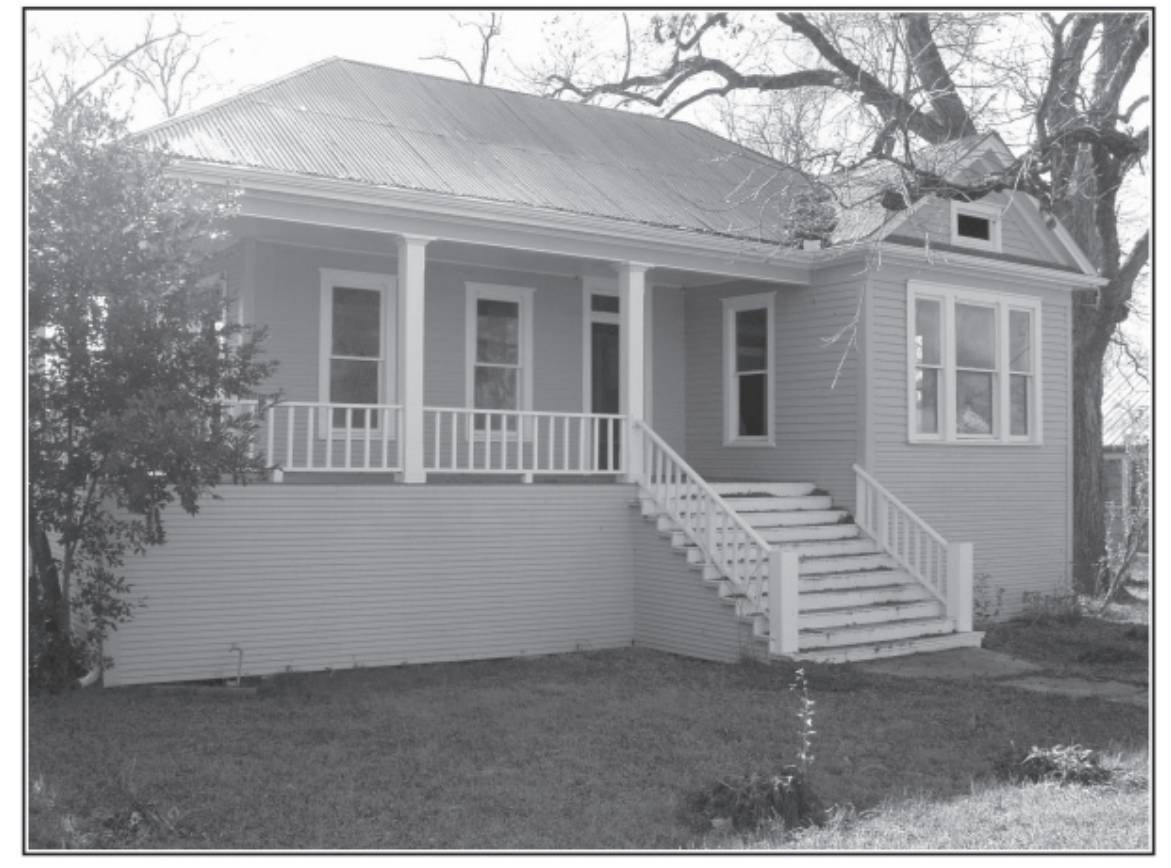

Figure 3-9. Beverly and Lula Kerr residence at 1305 Pine Street.

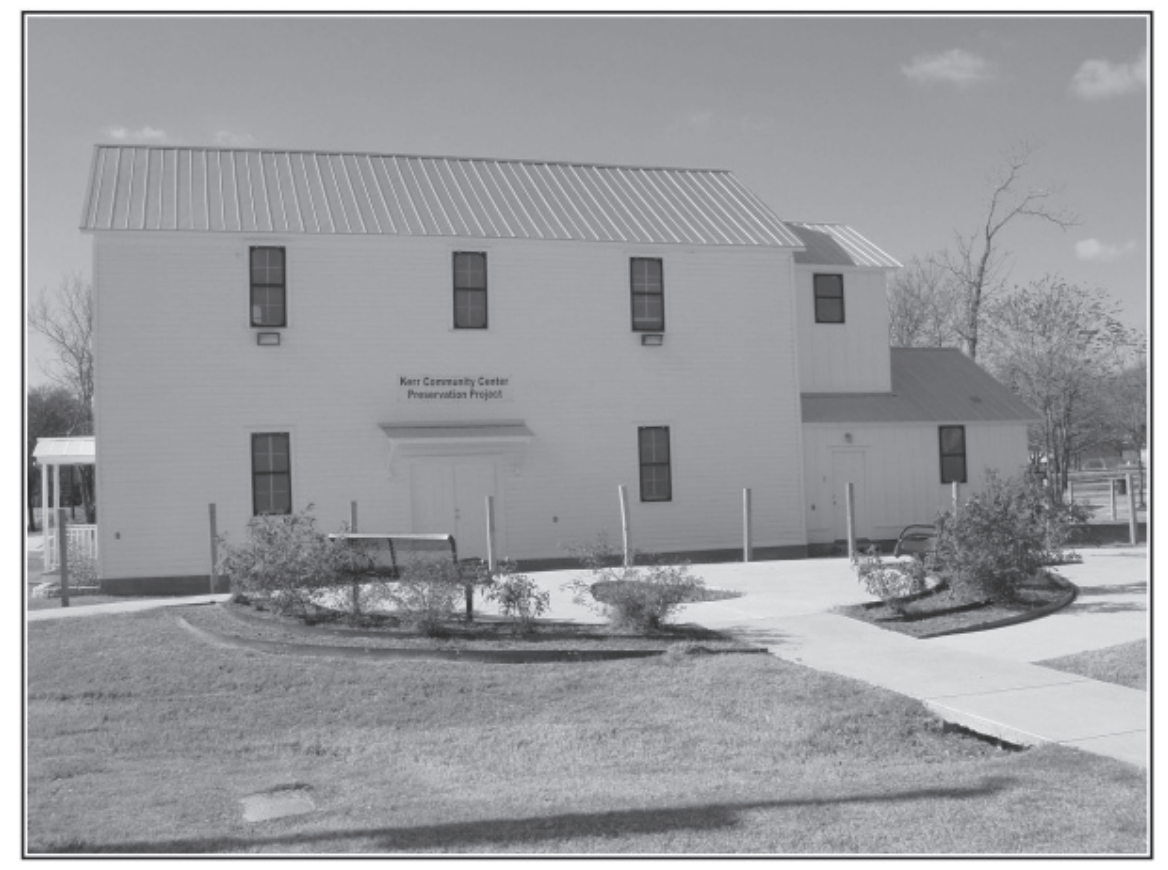

Figure 3-10. Kerr Community Center. 


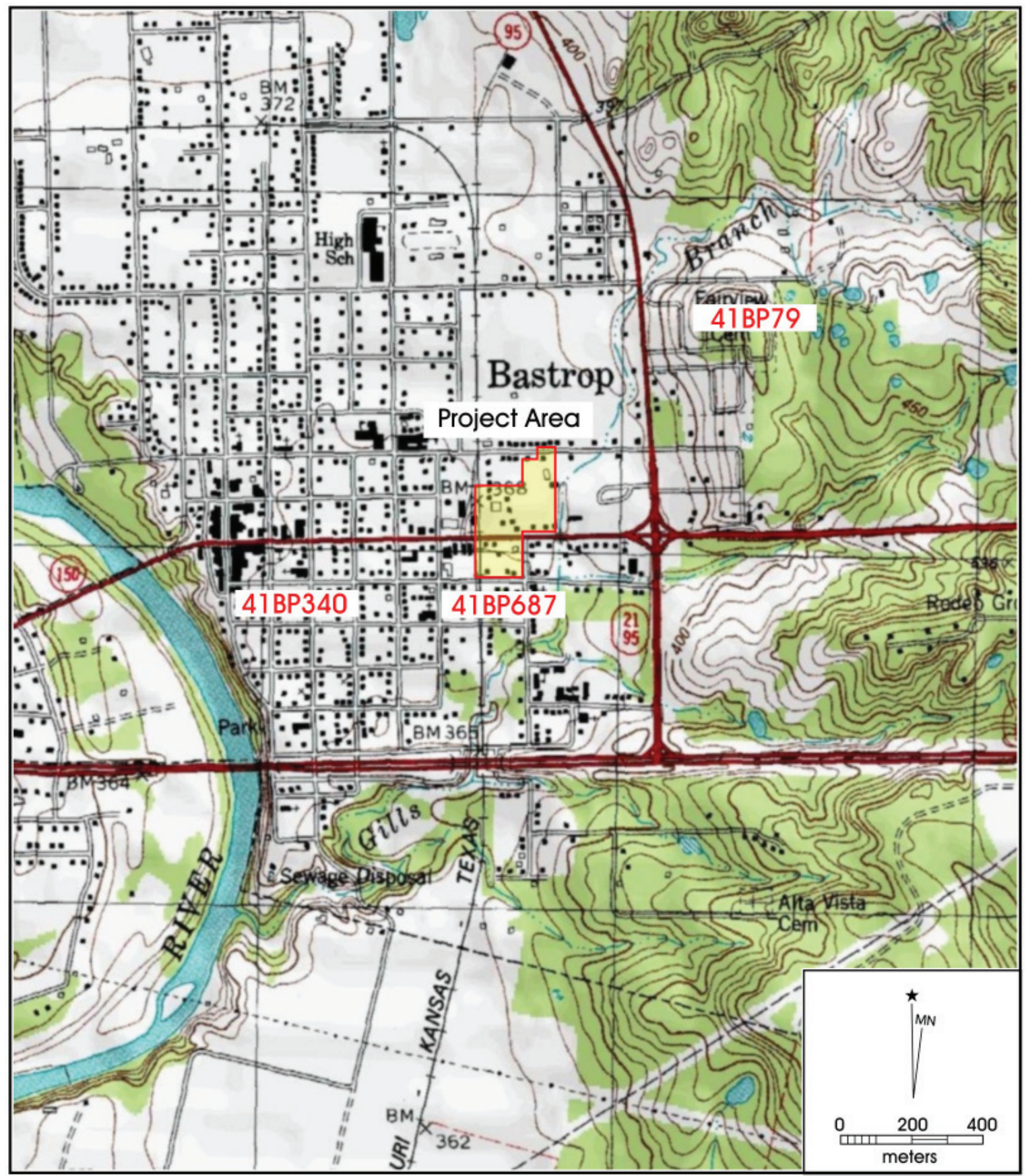

Figure 3-11. Recorded historic archaeological sites near the project area. 


\section{Chapter 4: Field Methodology}

The archaeological investigation of building Blocks 52, 53, 69 , and 70 consisted of reconnaissance walk-over surveys, systematic shovel testing, and backhoe trenching in selected areas. All four blocks were subjected to a pedestrian walkover survey, where the ground surface was examined for cultural material and features. Based on the survey area (6 acres), excavation required to fulfill the THC minimum survey standards for project areas from 3-10 acres is a minimum of 12 shovel tests (STs), at a density of $2 \mathrm{STs}$ per acre. Shovel test locations were spaced out across the landscape at 30-meter intervals when possible, except during the delineation of positive shovel tests. The strategic placement of shovel tests was somewhat hindered by the large degree of development currently existing within the APE, consisting of concrete foundations, road-base episodes, and standing structures. Since varied amounts of development exist in certain portions of the APE, shovel testing transects had to accommodate such obstacles. The majority of building blocks in downtown Bastrop consist of just over 10,000 square meters, but only areas where natural ground surface was accessible were shovel tested. GPS coordinates were captured for all 27 shovel tests and the three backhoe trenches (Figure 4-1).

Shovel tests measured $30 \mathrm{~cm}$ in diameter and extended to a maximum depth of 60 centimeters below surface $(\mathrm{cmbs})$, unless otherwise prevented. The shovel tests were excavated in 10-centimeter increments and all soil was screened though a $1 / 4$-inch hardware cloth. When cultural material was recovered from a shovel test, the shovel test was delineated at 10-meter intervals until two negative shovel tests in every cardinal direction were attained, or until a project area boundary or physical hindrance was encountered. Relevant information was recorded on a standardized form. All collected cultural material was brought back to the CAR laboratory for analysis.

Backhoe trenching was conducted in three high probability locales in an effort to determine if historic trails did indeed pass through the project area and to determine the presence/ absence of deeply buried deposits. To comply with the Minimum Survey Standards as defined by the THC, the backhoe trenches measured five meters long, about one meter wide, and one and a half meters deep. Back dirt and trench walls were inspected for cultural material, and profiles of the stratigraphy, including a description of soil types, were drawn for all three backhoe trenches.

For the purposes of this survey, an archaeological site had to contain a certain number of cultural materials or features older than 50 years within a given area. The definition of a site is: (1) five or more surface artifacts within a 15 -meter radius (ca. $706.9 \mathrm{~m} \mathrm{sq}$.), or (2) a single cultural feature, such as a hearth, observed on the surface or exposed in shovel testing, or (3) a positive shovel test containing at least three artifacts within a given $10-\mathrm{cm}$ level, or (4) a positive shovel test containing at least five total artifacts, or (5) two positive shovel tests located within 30 meters of each other.

The landscape within all four building blocks was inspected by means of a pedestrian walk-over survey, but ground visibility was very limited. The three backhoe trenches were aligned east/west, perpendicular to the trajectory of Gills Branch. Trench 1 was situated in the northeast corner of Block 70 in the only area where road-base was not visible on the ground surface. Trench 2 was excavated in the northeast corner of Block 69, skirting Gills Branch. Trench 3 was situated along the center of the northern boundary of Block 52 , in one of the few areas that was accessible. The three backhoe trenches were positioned on the northern half of the APE in an effort to "hit" the Camino Real's presumed course north of the project area, but backhoe trench placement was also designed to accommodate a close proximity to Gills Branch where deeper prehistoric deposits are more likely to occur. A minimum of 12 shovel tests were required to provide adequate coverage of the survey area, but a total of 27 shovel tests were excavated within the APE. Block 52 was subject to seven shovel tests situated between patches of road-base and standing structures. Fifteen shovel tests were excavated within Block 53, which also contained numerous patches of roadbase beneath the grass, but only a limited number of standing structures. Since an archaeological site was discovered in Block 53, boundaries of the site were established with shovel test delineation, and a datum with a field site tag was placed in the center. Two shovel tests were excavated within Block 69 and one on Marion Street along a large undisturbed tract. Finally, Block 70 was subject to only two shovel tests since almost the entire landscape of Block 70, falling within the APE, was coated in a thick road-base lens. 


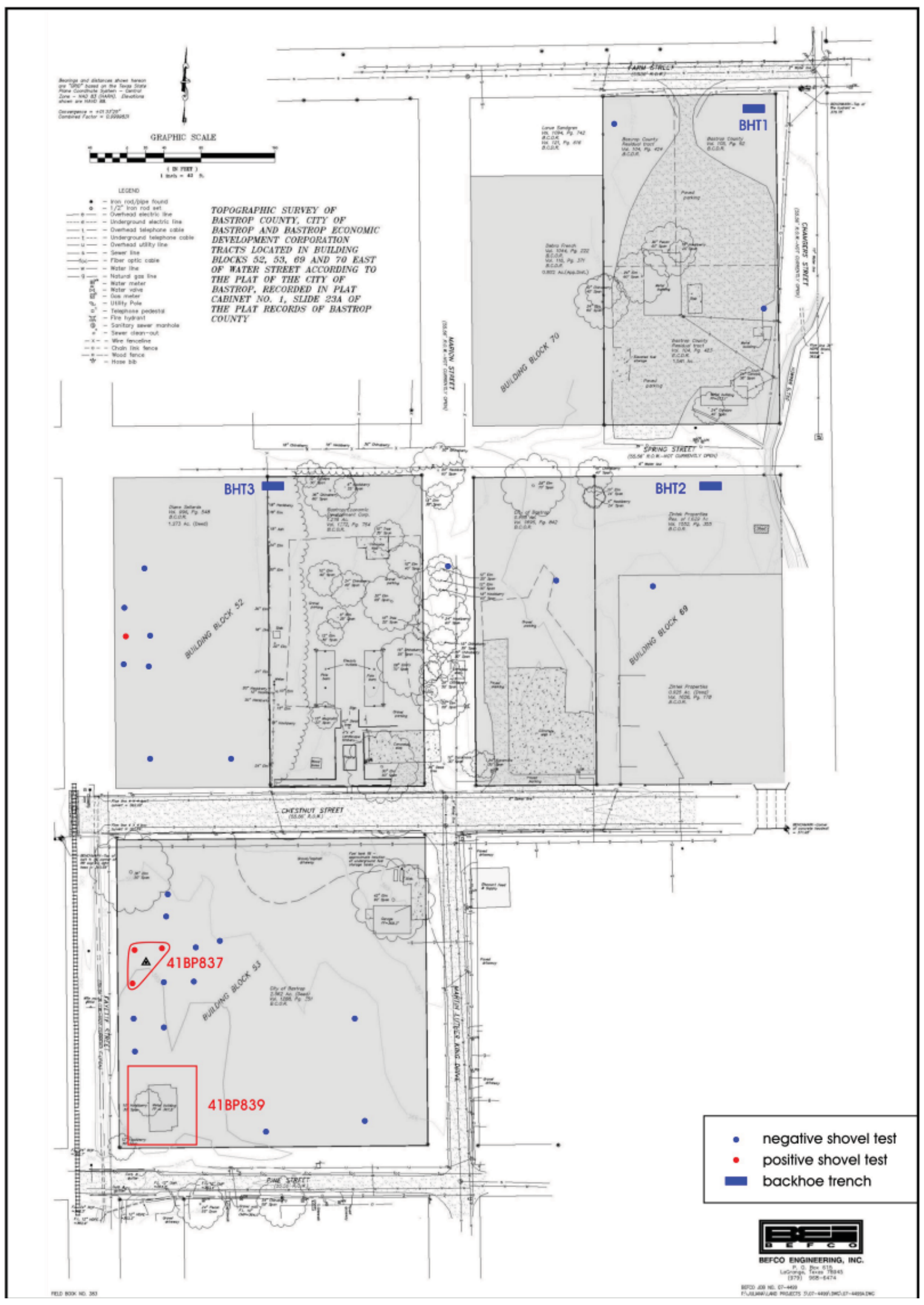

Figure 4-1. GPS locations of 27 excavated shovel tests, 3 backhoe trenches, and archaeological sites 41BP837 and $41 B P 839$ within the APE. 


\section{Chapter 5: Results of Field Investigations}

No cultural material was encountered on the ground surface during the pedestrian walk-over survey. The lack of surface artifacts may be due to numerous episodes of development over the course of the years. Backhoe Trench 1 exposed five artifacts, but not in a density that would indicate the presence of an archaeological site. Backhoe Trench 2 yielded one artifact, and Backhoe Trench 3 was negative. All three trenches contained sandy soils and only Backhoe Trench 1 exhibited a noticeable amount of disturbance, indicated by a $25 \mathrm{~cm}$ thick lens of road-base (Figure 5-1).

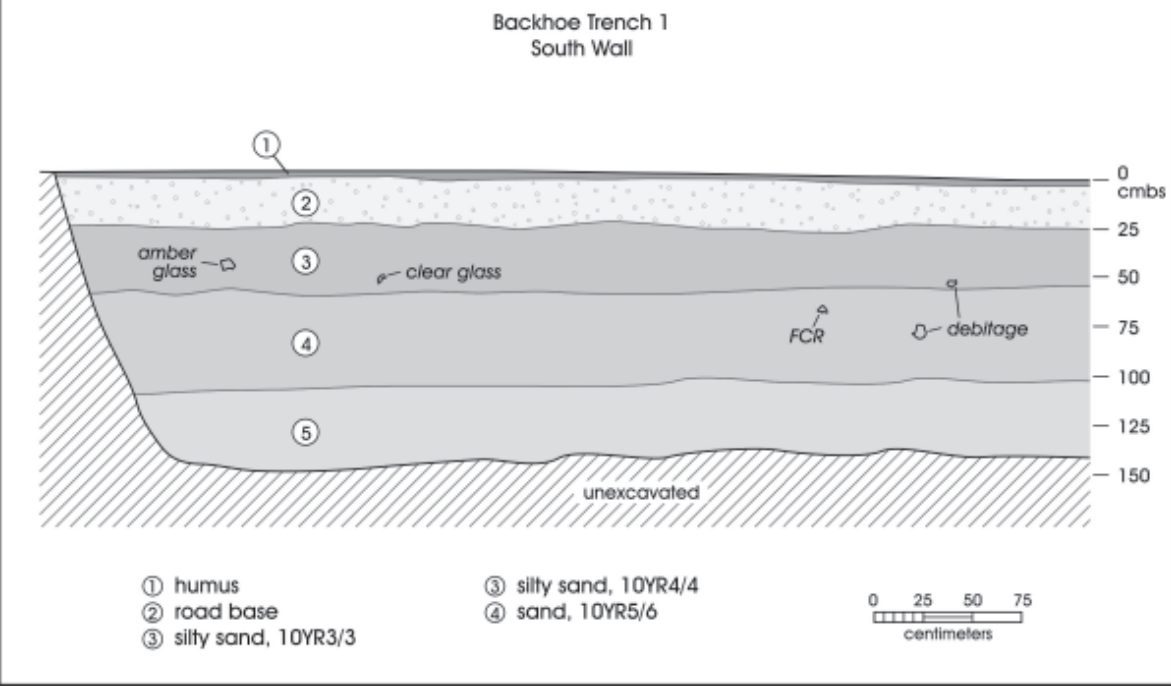

Figure 5-1. Trench 1 soil profile.

The systematic shovel testing of the project area revealed the presence of a small historic site in Block 53 that yielded 43 artifacts recovered from 3 separate positive shovel tests. A single shovel test in Block 52 yielded two artifacts. In sum, subsurface testing resulted in the recovery of 51 artifacts from the APE.

Also, further photo-documentation of the historic "Texas Company" depot structure in the southwest corner of Block 53 occurred, and the landscape surrounding the structure was adequately shovel tested. No remaining material evidence was encountered to suggest that the Camino Real route rested within the APE, as is hinted at by the V.N. Zivley map from 1915 (Figure 5-2).

\section{Backhoe Trenching}

Backhoe Trench 1 revealed five non-diagnostic artifacts from varying strata (see Figure 5-1). Two pieces of lithic debitage, one heat spall, one clear glass bottle base fragment, and one piece of amber bottle glass were recorded and collected. Standard amber colored glass has seen an extensive time period of use and has very little dating utility. Amber glass is extremely common to this day, due to its ability to block out wavelengths that lead to off-flavor chemical reactions in various libations (SHA 2008). It is uncertain whether the bottle glass recovered from Backhoe Trench 1 is historic or modern, but given the varying degrees of disturbance over the landscape, it is unlikely they are modern. According to the revised Sanborn map from 1921, no structures stood in Block 70 (DSM 2008), but the recovered bottle glass lacks sufficient diagnostic utility to suggest they are associated with a historic occupation in this area. Moreover, the ground surface has been severely impacted by a thick and compact lens of road-base, covering nearly the entire property, hindering further examination. Two shovel tests west and south of Backhoe Trench 1 were excavated in areas with minimal road-base on the surface, but no cultural material was encountered.

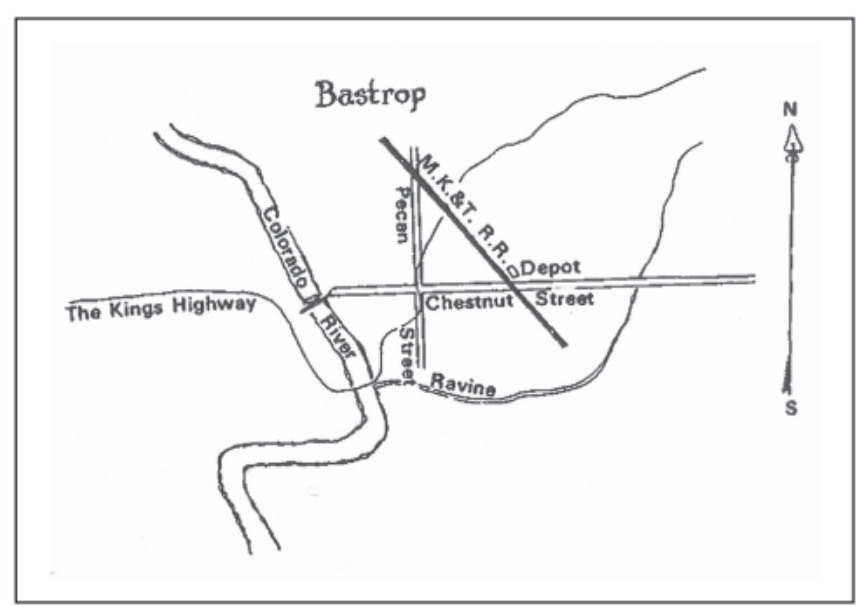

Figure 5-2. V.N. Zivley 1915 map of Camino Real. 
Backhoe Trench 2 yielded an isolated piece of fire-cracked rock. Three shovel tests were later excavated south of Trench 2, but they yielded negative results. Both positive backhoe trenches yielded too few artifacts in a dense enough concentration to indicate the presence of an archaeological site, and surrounding shovel tests did not indicate the presence of any additional cultural remains.

\section{Systematic Shovel Testing}

The shovel testing component of this survey's field methodology yielded a total of 45 artifacts, and revealed a small historic site in Block 53. Artifacts associated with the historic site totaled at 43 , and were recovered from shovel tests 17, 20, and 22. Cultural material consisted of 3 pieces of undecorated white earthenware ceramic ( 2 body sherds and 1 rim sherd), 10 unidentified large mammal long bone fragments, 1 piece of clear chimney glass, 3 ferrous metal fasteners, 15 clear bottle glass fragments, 1 amber bottle glass body fragment, 3 pieces of milk-glass ( 2 body fragments and 1 base fragment), 1 aqua glass bottle base fragment, 1 piece of flat window glass, and 5 specimens of "old" amber glass bottle body fragments. These materials were recovered from deposits from 20 to 40 centimeters below ground surface.

Shovel Test 8 in Block 52 yielded two specimens of lithic debitage, but further shovel tests to delineate Shovel Test 8 were negative. Block 52 contained an extremely high degree of surface road-base, concrete foundations, and large standing structures preventing the excavation of more than eight shovel tests.

\section{Archaeological Site 41BP837}

Archaeological site 41BP837 is a small historic site resting immediately east of the railroad berm running north/south through the western boundary of the APE (see Figure 4-1). The cultural materials associated with this site have very little diagnostic value, but they do possess some temporal information. As mentioned above, five specimens of "old" amber bottle glass were recovered from the site. "Old" amber is a color scheme that is not common in glass bottles created after 1890 (SHA 2008). After the 1920s, machine-made bottles and glass chemistry was refined to the point where off-color shades of amber became increasingly uncommon. Three specimens of milk-glass were recovered from this site (Figure 5-3). Opaque white glass, or milk-glass, was created by adding tin or zinc oxide, fluorides, and phosphates to the glass chemistry (Kendrick 1968). Its manufacture caused additional wear and tear on glass melting pots and tanks, and was therefore limited to certain factories willing to produce it. Milk-glass also has some limited diagnostic utility. It was used primarily for cosmetic and toiletry bottles from the 1870 s to the 1920 s, and as ointment/cream jars from the 1890s to the mid-twentieth century (U. of U. 1992). Unfortunately, the undecorated white-earthenware ceramics have little temporal utility in the dating of these deposits. Site 41BP837 is most likely a historic trash deposit consisting of discarded materials associated with railroad-related activities from what may have been a railroad depot with three satellite structures situated in this locality as early as 1887 , as will be discussed further in Chapter 6. It is also possible that this site consists of remnants of activities related to a dwelling that rested in this area as early as 1921, based on Sanborn maps.

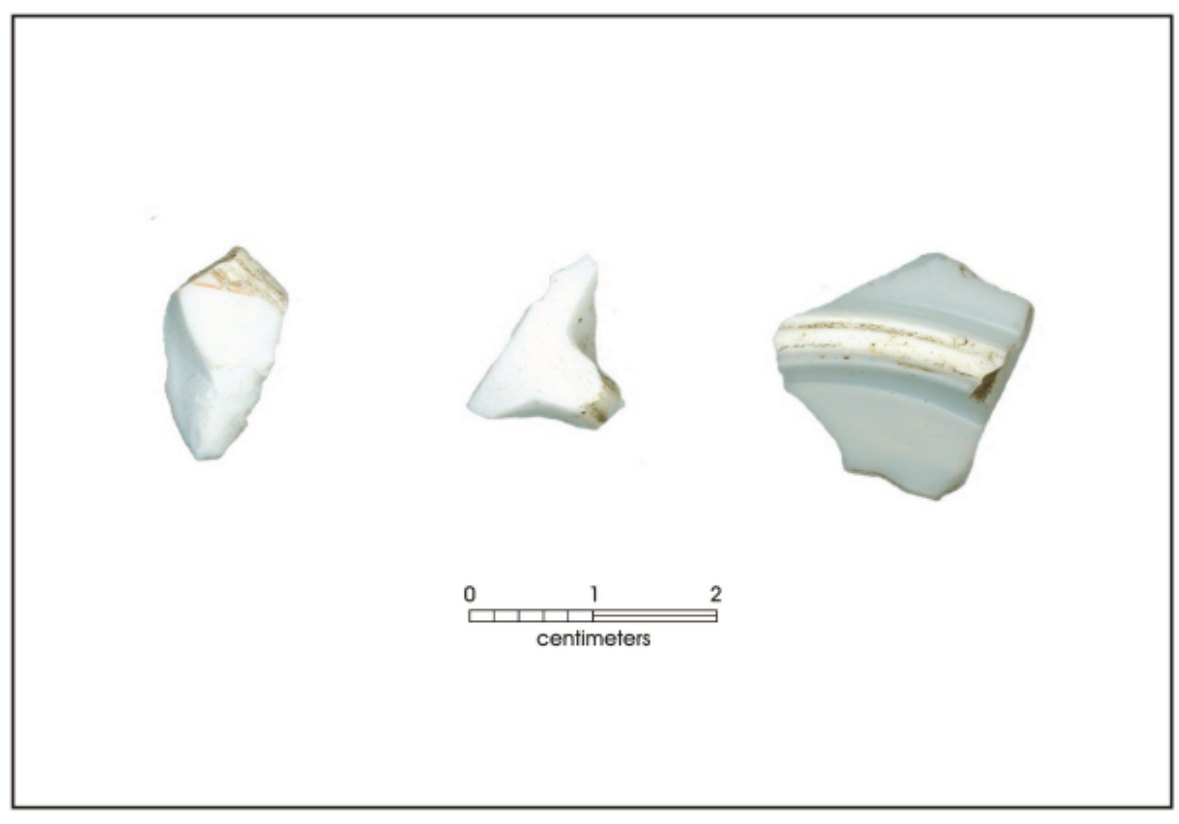

Figure 5-3. Recovered milk glass artifacts from $41 B P 837$. 


\section{Chapter 6: Archival Research}

Archival research on properties within the APE, as needed to complete a historic structures assessment, consisted of compiled data derived from the Bastrop Central Appraisal District, Bastrop County Clerk's Office, online historic digitized Sanborn maps, and Amon Carter Museum historic maps of Bastrop County. This data was synthesized in an effort to understand more of the background of the historic "Texas Company" depot, 41BP839, present in the southwest corner of Block 53 and archaeological site 41BP837 resting immediately north of it. Archival data acquisition on a residential structure in Block 69 was also completed to establish its long presence in Bastrop's Historic District.

\section{Area of Potential Effect}

Very rough historic sketches of the Bastrop township were created in 1887 by Augustus Koch, and are available at the Amon Carter Museum's website (ACM 2008). These "bird's eye" view maps offer some insight into the original structures that stood in the overall project area. No standing structures rested on Block 52 in 1887. Block 53 contained a single structure in the southeast quadrant, and a structure (possible railroad depot) was present in the northwest quadrant (Figure 6-1). The latter structure was complimented by three smaller satellite structures that were in the immediate proximity of site 41BP837. Two residential structures stood in the southeast quadrant of Block 69 . Block 70 was entirely vacant.

Digital Sanborn maps for the project area's locality were available on-line from three different time periods. However, a major discrepancy in the 1921 map of this area was encountered, and city block numbers and street names had to be recalibrated using a distinctively shaped structure labeled the "Macedonia Baptist Church" in Block 67 as a reference point. The other two Sanborn maps from 1934 and 1934-44 were both correct and did not require revisions. Therefore, the corrected Digital Sanborn maps (DSM 2008) indicate that in 1921, Block 52 contained five structures in the southern half of the block (Figure 6-2). Block 53 had two structures in the northwest corner, and one structure each in the southwest and southeast corners. Within Block 69, stood the dogtrot dwelling at 1408 Chestnut Street, and two structures in the

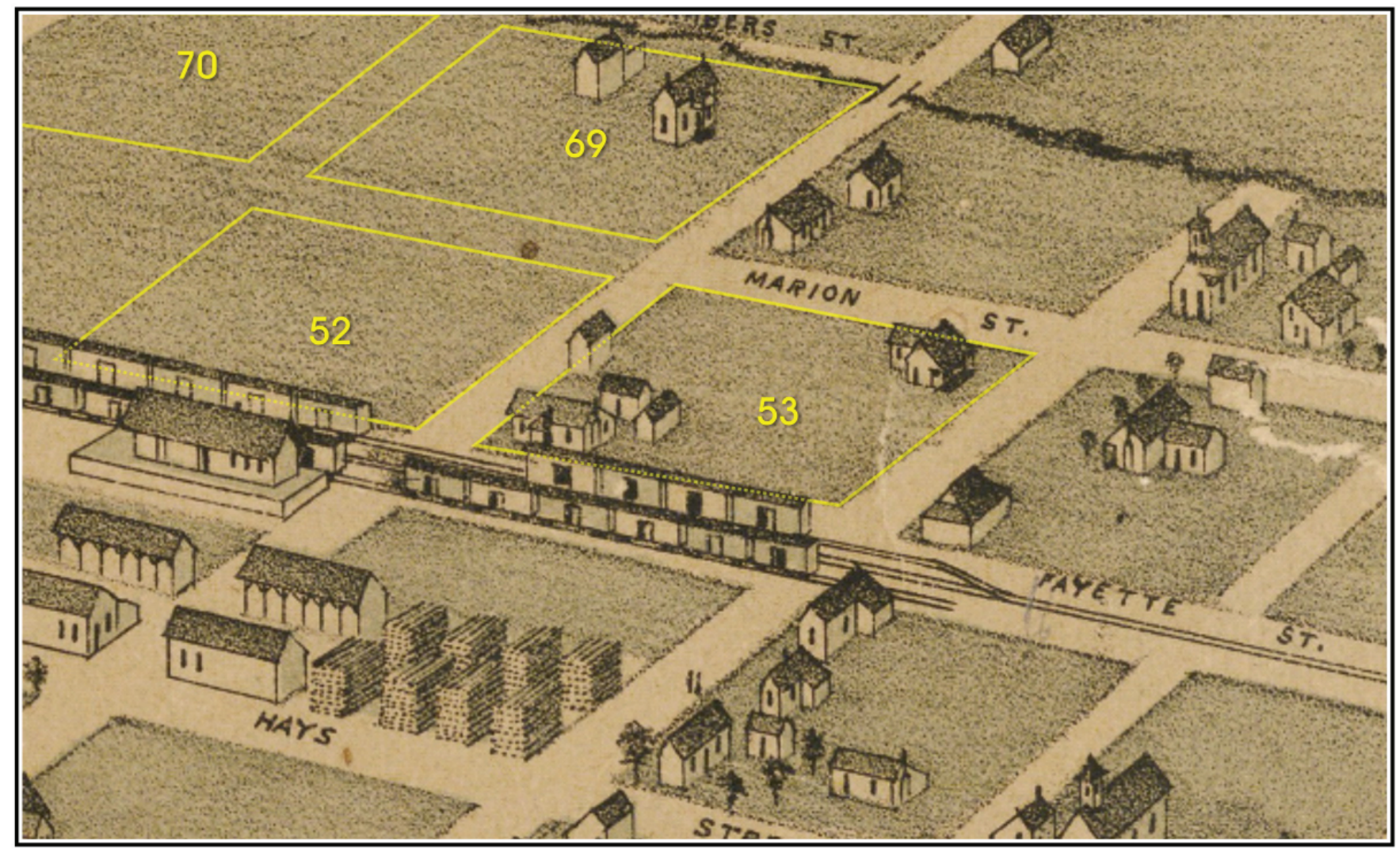

Figure 6-1. Augustus Koch's 1887 Bird's Eye View sketch of Block 53. 


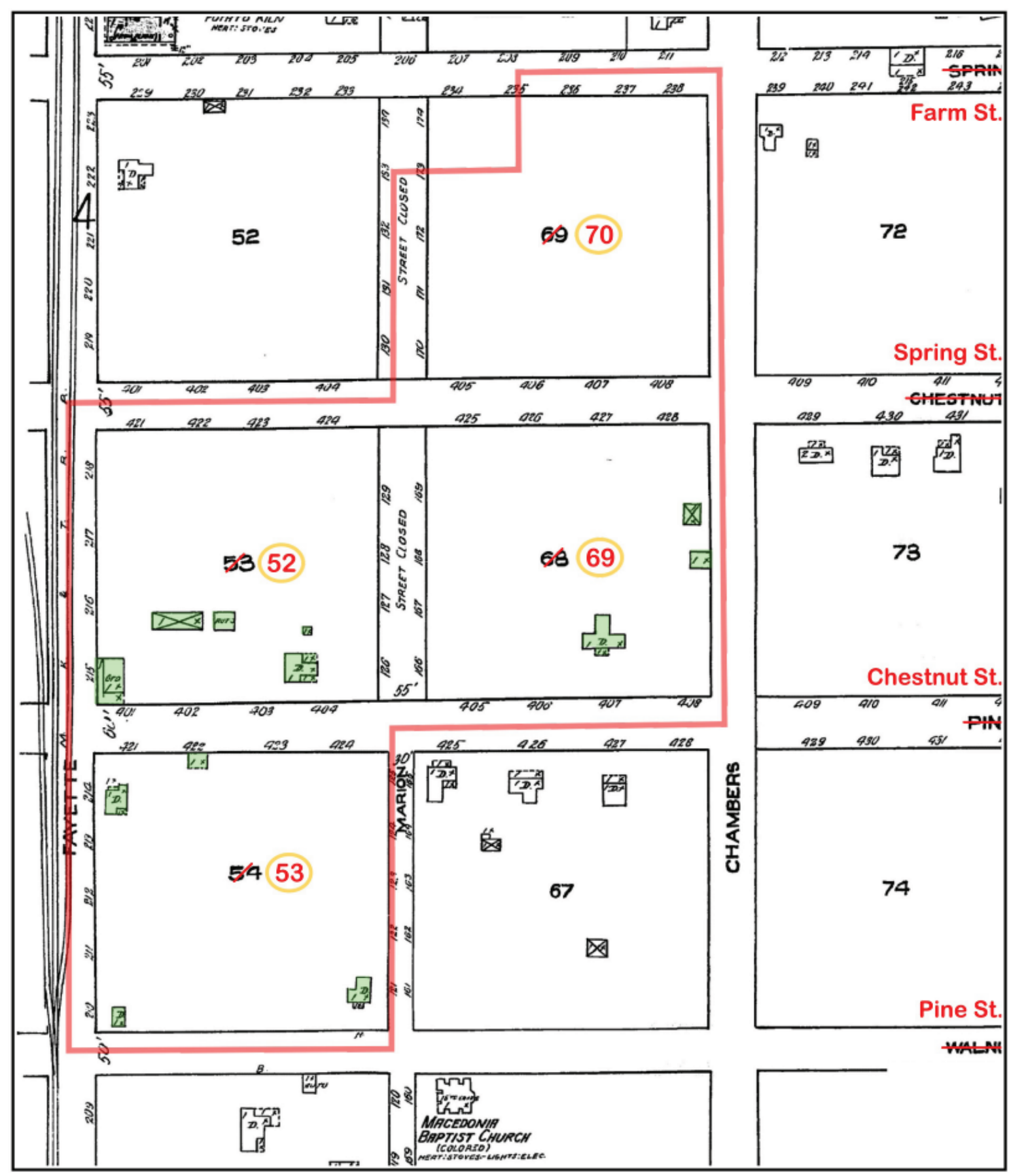

Figure 6-2. Sanborn map from 1921.

northeast quadrant of the block. Block 70 was entirely void of any standing structures.

The 1934 Sanborn maps for Block 52 illustrate all of the previously mapped structures from the 1921 map with one additional structure in the southern half (Figure 6-3). Also, a structure that was a grocery store in the southwest corner was replaced or remodeled, and a dwelling existed there by 1934 .
Block 53 no longer contained a structure in the southeast corner, but gained two additional structures in the northeast corner, as well as one more structure in the southwest quadrant of the block. Four new structures were constructed in 1934 in the southern half of Block 69, one of which was the Texas Highway Department building. The 1934 map indicates the construction of a single structure in the southeast corner of Block 70. 


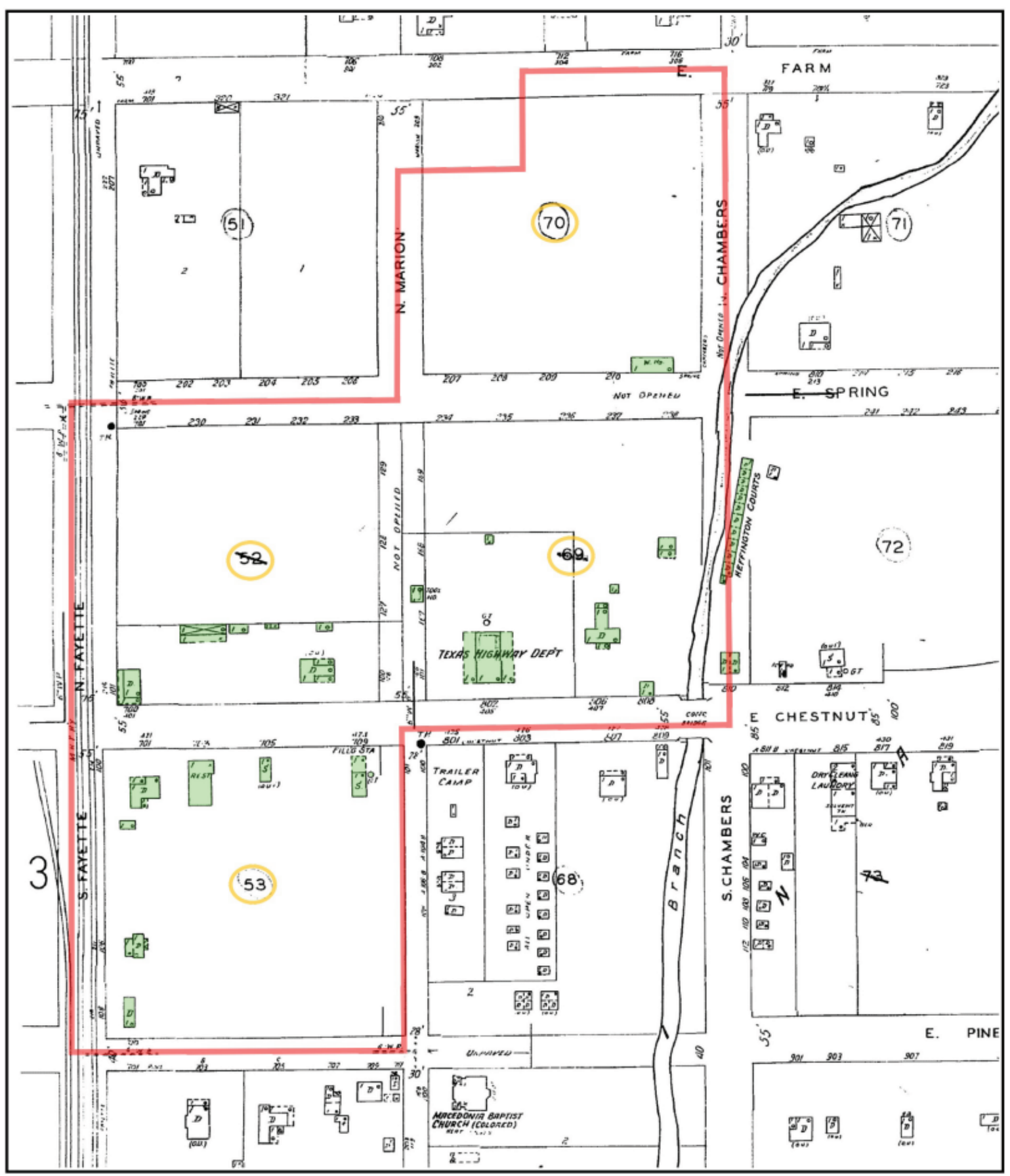

Figure 6-3. Sanborn map from 1934.

Sanborn maps from the 1934-44 time period show little change for Block 52 (Figure 6-4). Most of the standing structures on Block 53 were removed, with the exception of the dwelling and its satellite structure in the northwest corner, and the dwelling in the southwest corner. Block 69 remained the same, with the exception of a single structure added to the southeast corner. No changes occurred in Block 70 during this time.

\section{Historic "Texas Company" Depot in Block 53}

The southwest corner of Block 53 contains what appears to be a historic freight depot for what is currently known as the Texaco Company. The structure (41BP839) consists of posts and beams with corrugated metal panel sheathing and roof, erected on an elevated foundation (Figure 6-5). On the east side of the building is a loading platform, stretching nearly 


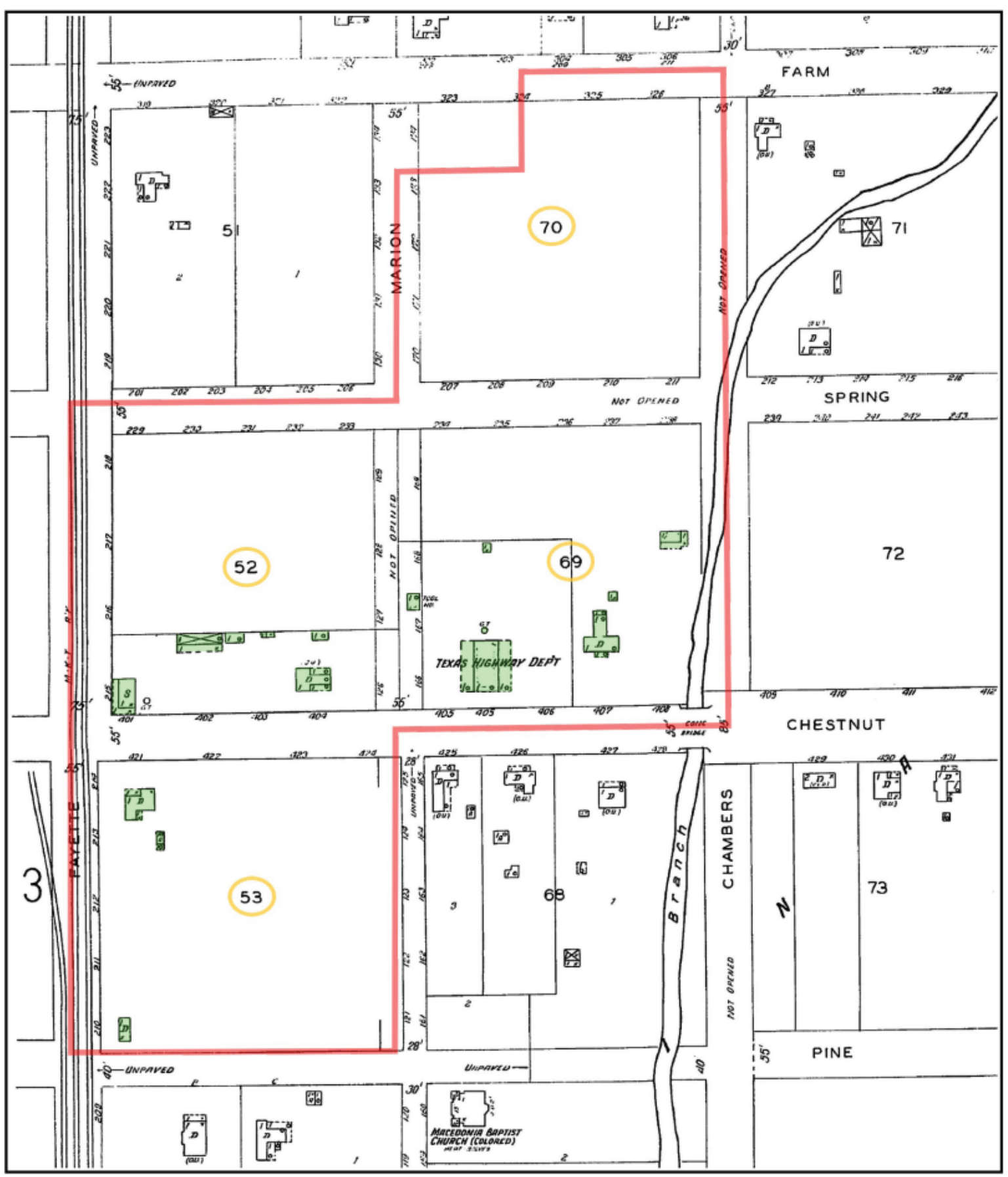

Figure 6-4. Sanborn map from 1934-1944.

the full width of the depot. Overhanging it is a full-width eave. Fenestrations indicate that the larger storeroom occupied twothirds to three-fourths of the building, with an office at the east end. The structure is in fair condition. The north wall of the structure reads "The Texas Company, USA, Texaco Petroleum Products" (Figure 6-6). The Texaco oil company formally went by the name the "Texas Company" until officially changing its name to "Texaco Inc." in 1959 (Figure 6-7).
Sanborn maps from 1921 to 1945 indicate that a structure was situated in this locality (DSM 2008), but this evidence does not incontrovertibly signify that this Texaco Depot is the same structure, and the approximate positioning on the Sanborn map does not correlate well with the structure's current location. Furthermore, the structure plotted in this vicinity of the Sanborn maps is labeled a dwelling. The Bastrop 9-1-1 Addressing Company does not have a 


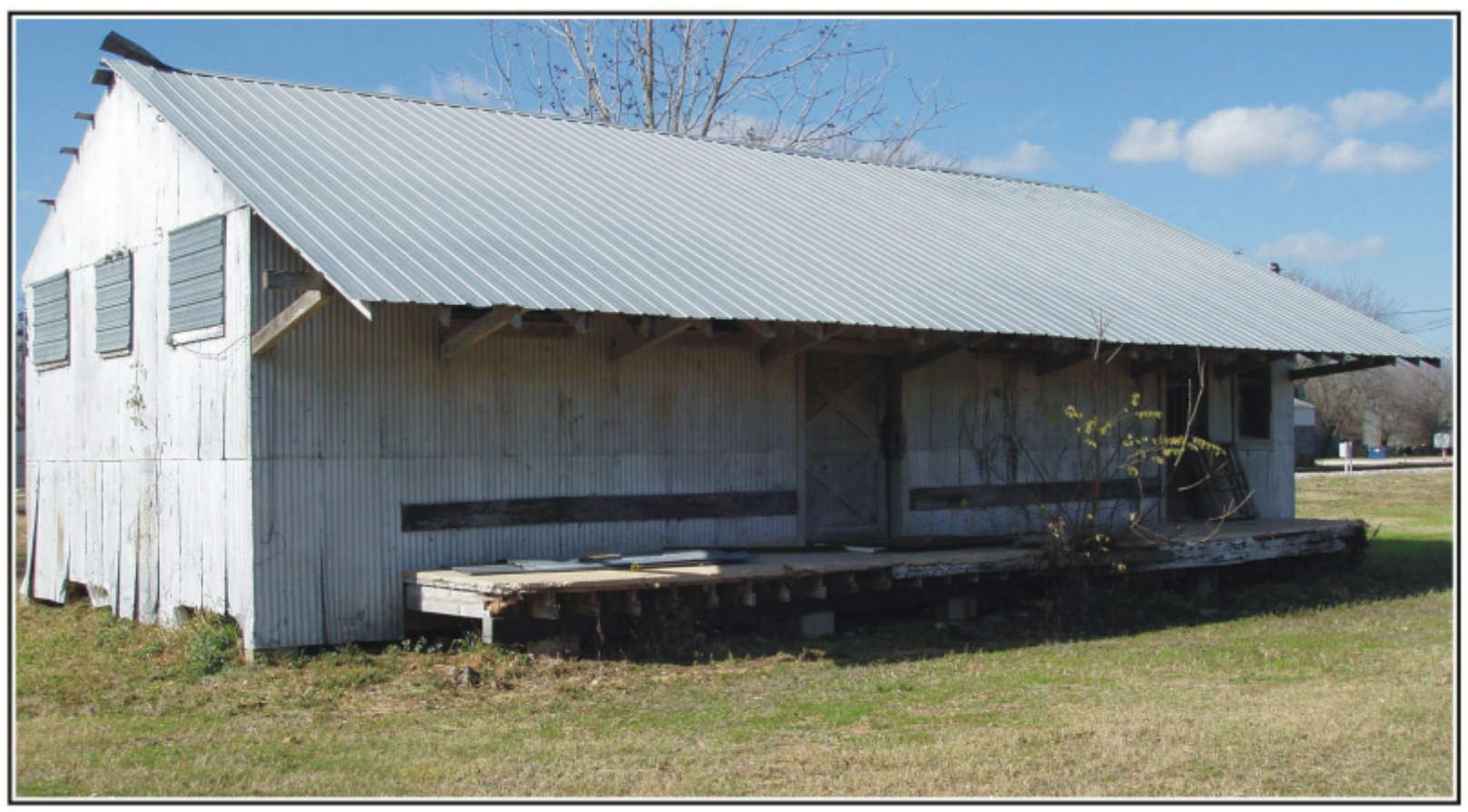

Figure 6-5. "Texas Company" structure in southwest quadrant of Block 53.

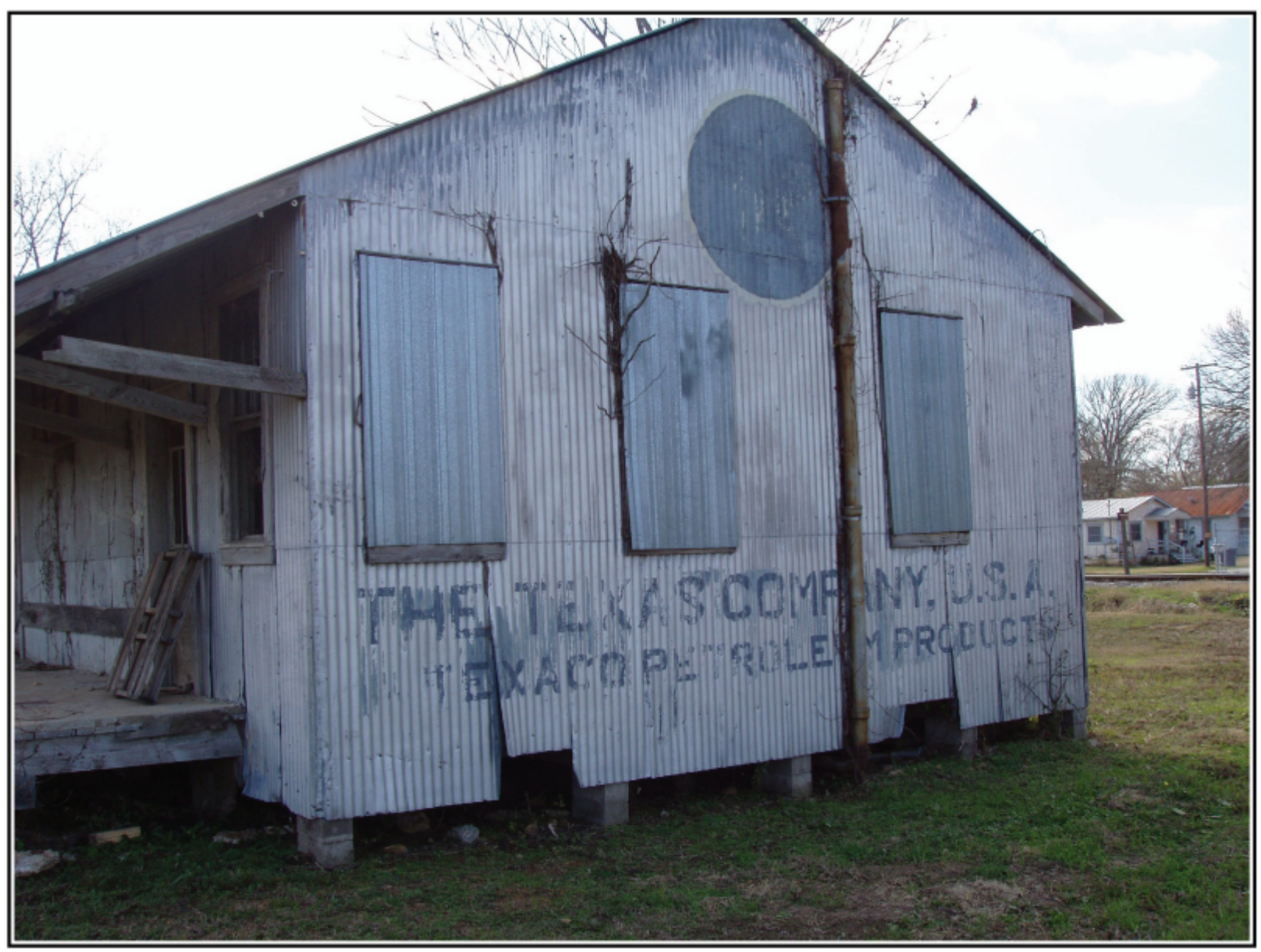

Figure 6-6. Company title adorning "The Texas Company" structure. 


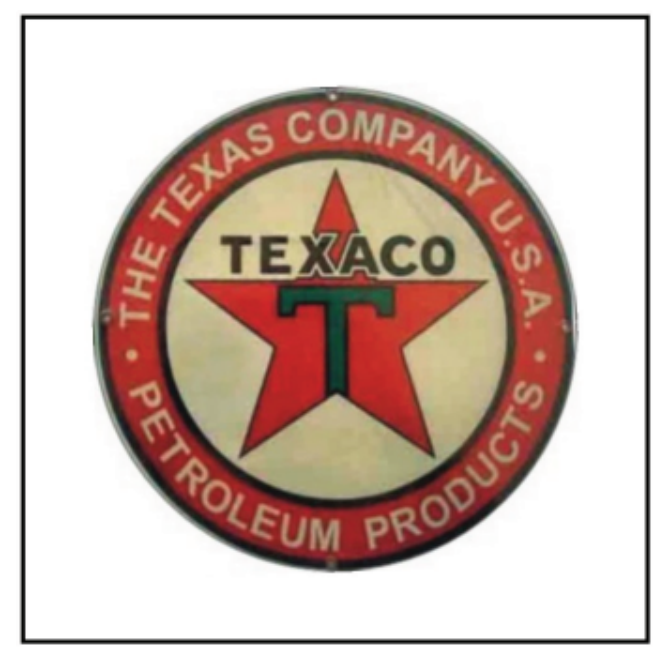

Figure 6-7. Vintage "Texas Company” logo.

registered address for the depot structure, suggesting it might have been moved from its original location. The Bastrop County Clerk's Office does not have any records of either "Texas Company" or "Texaco" owning land in, or around, the project area as a grantee. However, records do indicate that the "Texas Company, a corporation of Delaware", had leased property in the southwest corner of Block 52 in 1932 (BCCO 1932:99). This land was leased for the "business of distributing petroleum products" (BCCO 1932:100). By 1934, Block 52 did see the addition of a structure in the southwest corner, but the land record explicitly states the area to be leased as extending east from the southwest corner a distance of 50 feet, proceeding north 40 feet, turning west and proceeding 50 feet, and closing out the tract at 40 feet to the south (BCCO 1932:99). The Sanborn maps from 1921 forward indicate a structure was present in this area that served as a grocery store and then a dwelling. However, no commercial structures in the area explicitly described by the lease were added to Block 52 by 1934 according to the Sanborn maps. It is likely that the mapping of the "Texas Company" depot did not occur, or that during the genesis of the later Sanborn maps, a discrepancy occurred.

Furthermore, it is highly probable that this structure was moved south onto Block 53 and used for storage sometime after the "Texas Company's" lease expired. As stated earlier, Bastrop County has seven addresses listed within the APE, but no address has been registered for the "Texas Company" structure (Figure 6-8). The loading platform of this structure

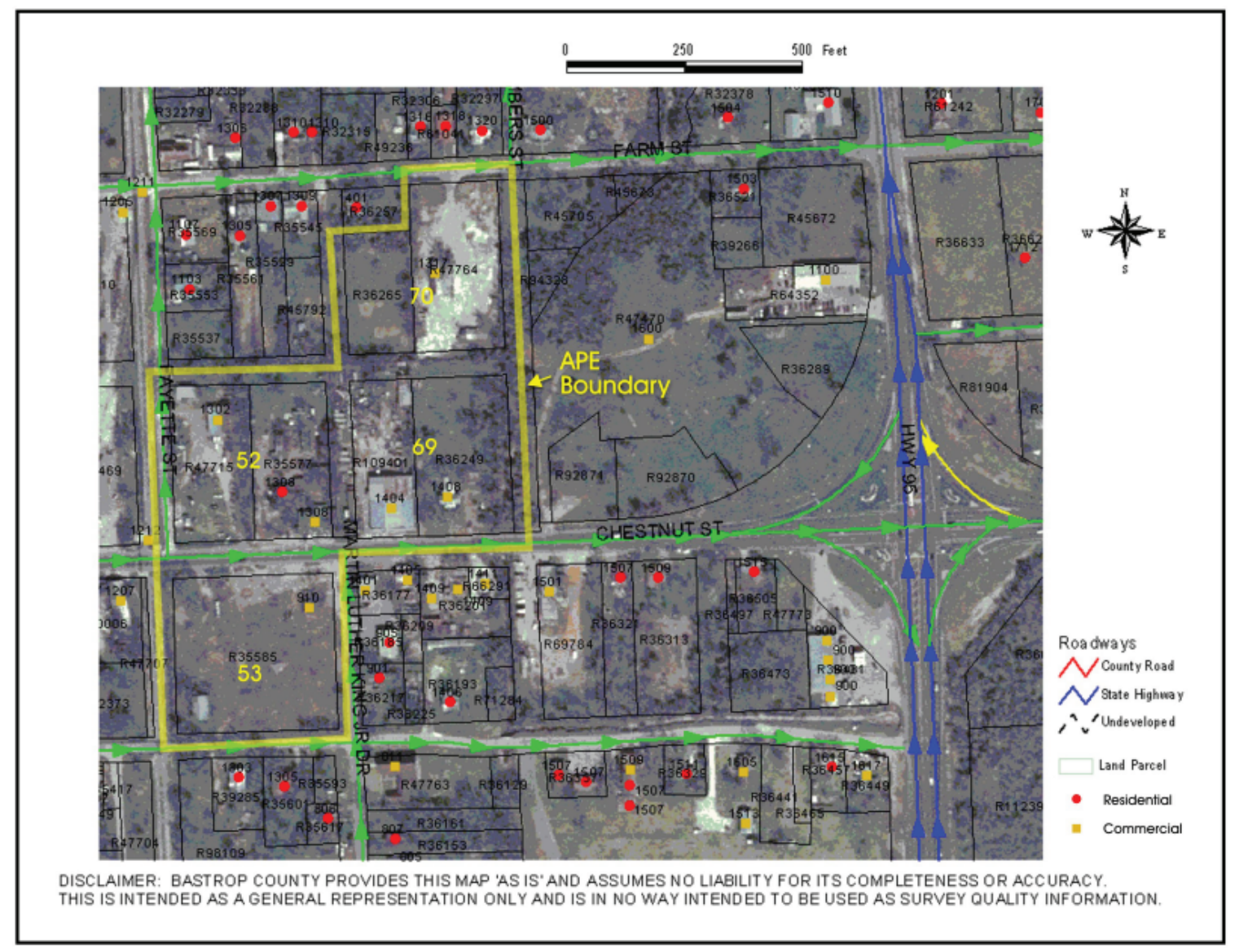

Figure 6-8. Aerial of APE illustrating the seven registered addresses within the project area. 
is also currently not facing the railroad which would not be conducive to the receiving of petroleum parts and fuel from the railroad. Sections of this structure rest on top of a makeshift network of large wooden beams and cinderblocks, which also implies that the structure may have had a "nomadic" past (Figure 6-9). Presently, the "Texas Company" structure contains various belongings of the Martha $\mathrm{M}$. Smith family, the previous owners who sold Block 53 to the County of Bastrop. The key to this locked structure is in the City Manager's Office.

\section{Historic Residential Structure at 1408 Chestnut in Block 69}

The structure at 1408 Chestnut Street in Block 69 was once a typical dogtrot with its main flanking rooms bisected by a centralized breezeway (Figure 6-10). Dogtrot houses are typically one-story farmhouses with a front porch. The construction date is believed to be 1880 (BCAD 2008:R36249), but previous owners concur that it was erected around 1865 . This structure, originally residential in nature, has recently been used for a long series of commercial functions. Currently it houses a beauty salon. The centralized breezeway has been enclosed to create a large greeting room for business purposes. The new greeting room is entirely modernized, with the two flanking rooms maintaining many of their original architectural characteristics, including the original longleaf pine floorboards, feeder beams and interior board and batten walls (Figure 6-11). The walls show signs of hole-repair with makeshift materials (door hinges, scrap metal, etc.). Repair materials were limited during the Great Depression of the 1930s, and makeshift repairs were common (Figure 6-12). All the ceilings of the structure have been replaced, as have many of the interior walls. The exterior façade of the structure has been completely remodeled with modern building fabrics. A well is still situated in the northwest portion of the property (Figure 6-13), but according to the Sanborn maps it is not contemporaneous with the structure, or was simply not large enough to be documented. The property also contains a noncontributing barn structure in the northwest corner. structure.

\section{Historic Archaeological Site 41BP837 within Block 53}

Archaeological site 41BP837 is most likely a historic trash midden resulting from activities associated with one of the four structures depicted in the northwest quadrant of Block 53 in Augustus Koch's 1887 drawing of the Bastrop township (see

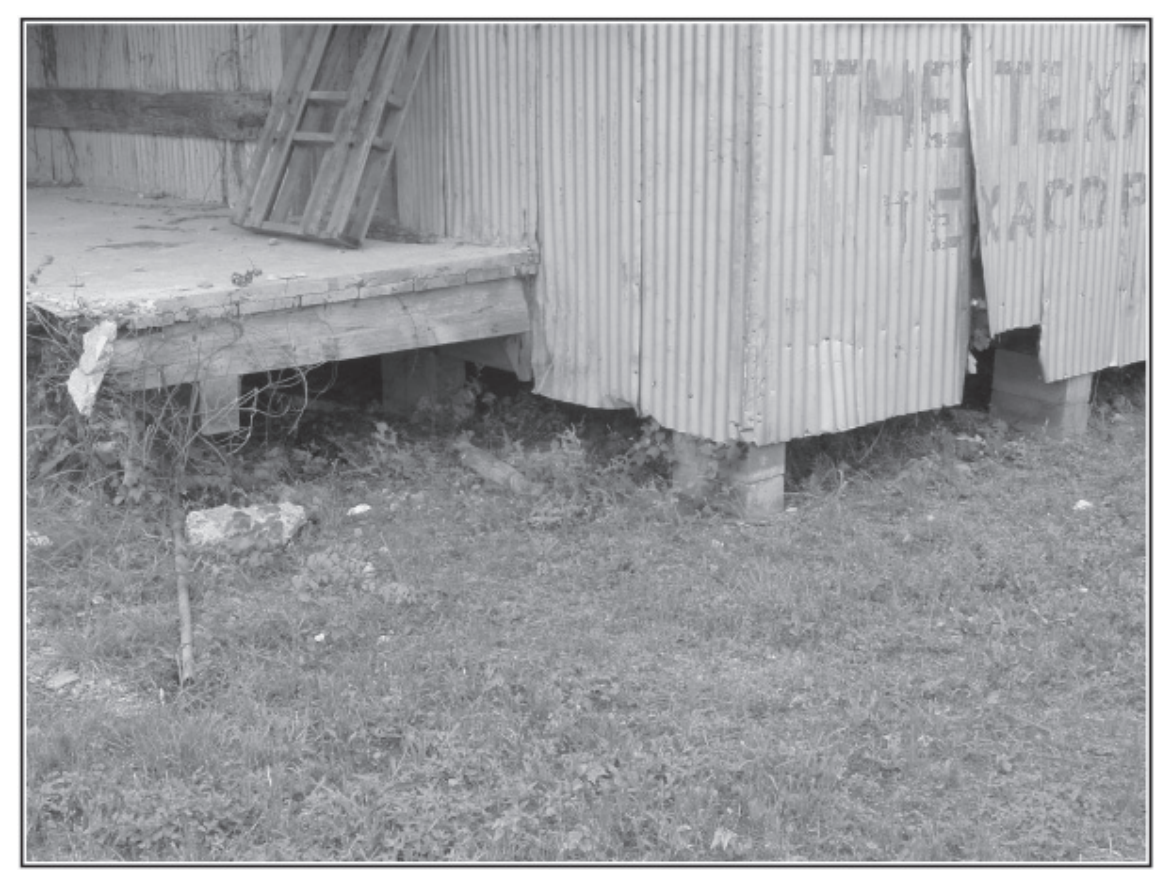

Figure 6-9. Foundation network of cinderblocks and beams under "Texas Company"

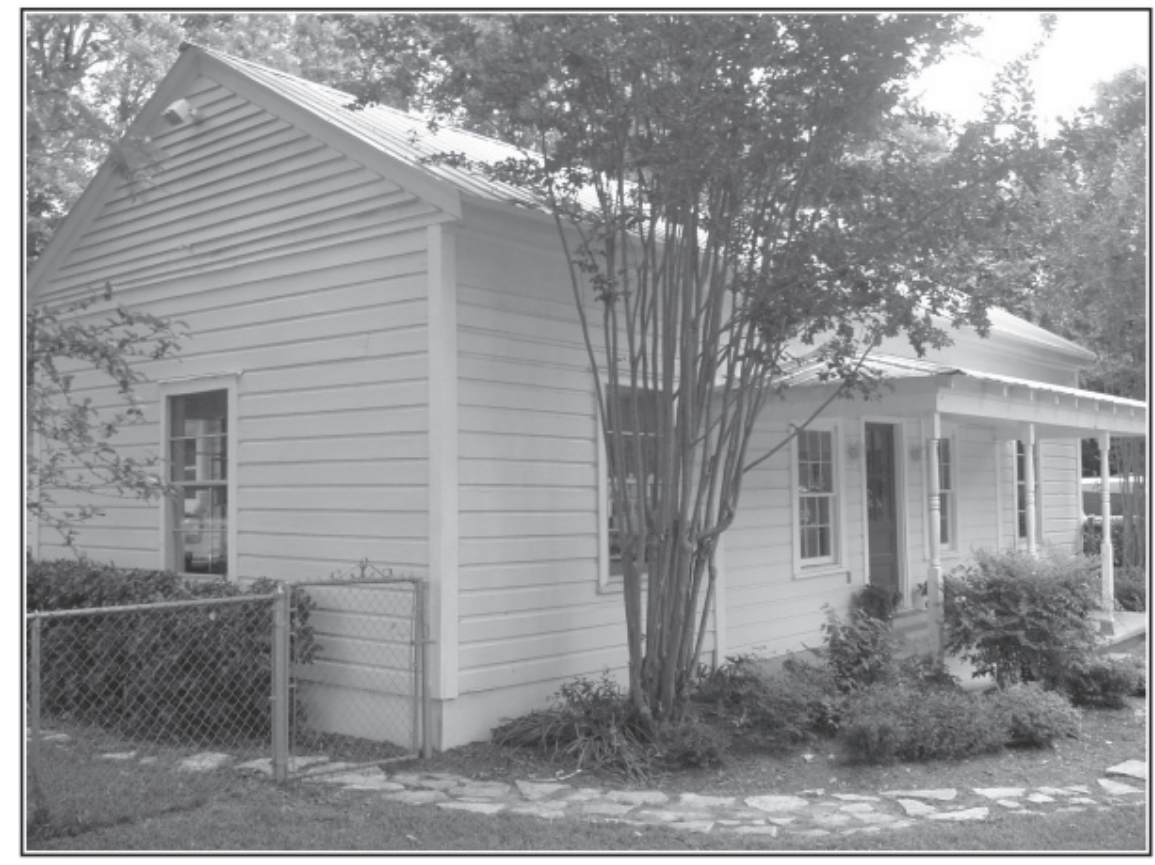

Figure 6-10. Historic residential structure at 1408 Chestnut Street. 


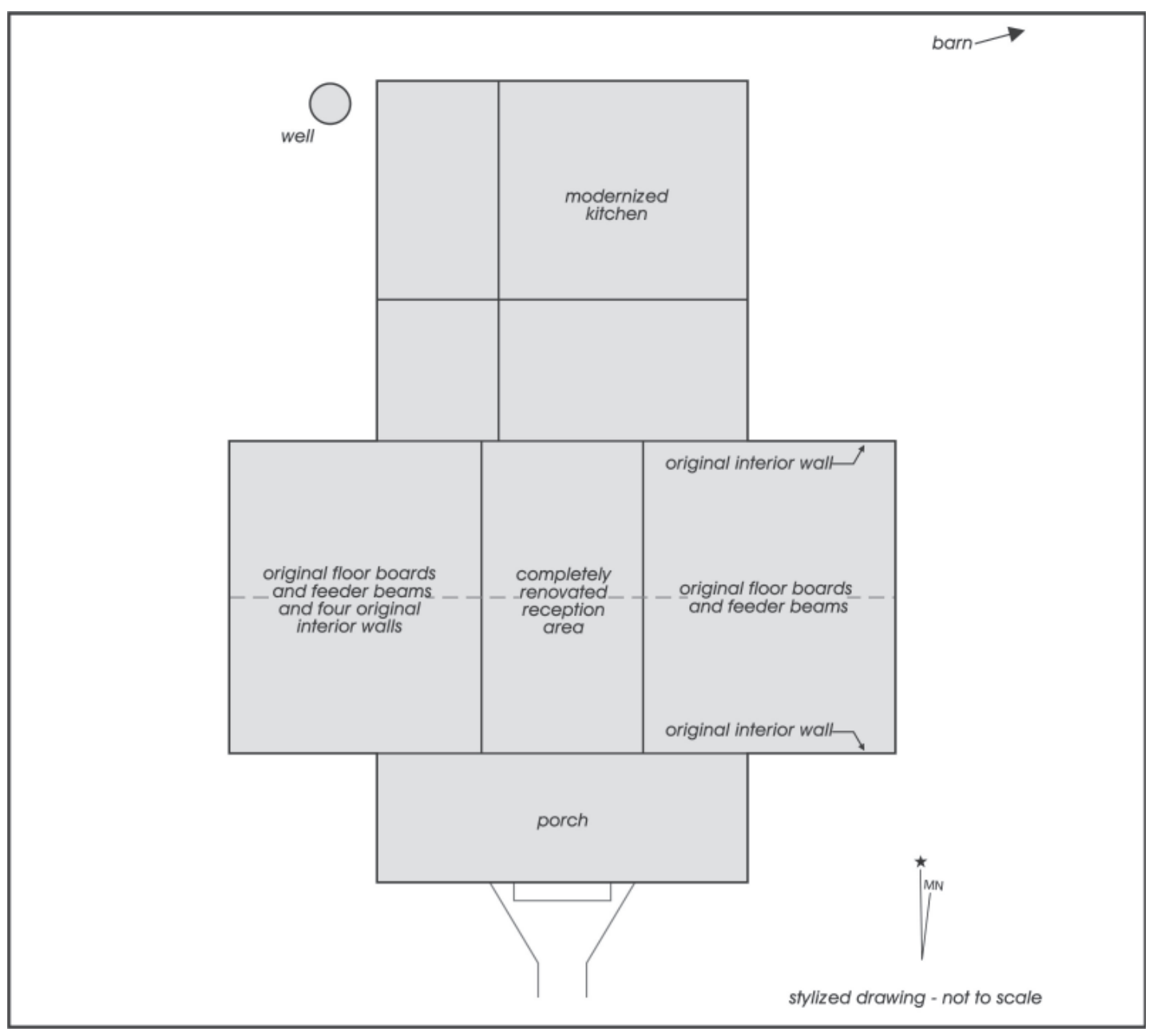

Figure 6-11. Floor plan of structure at 1408 Chestnut Street.

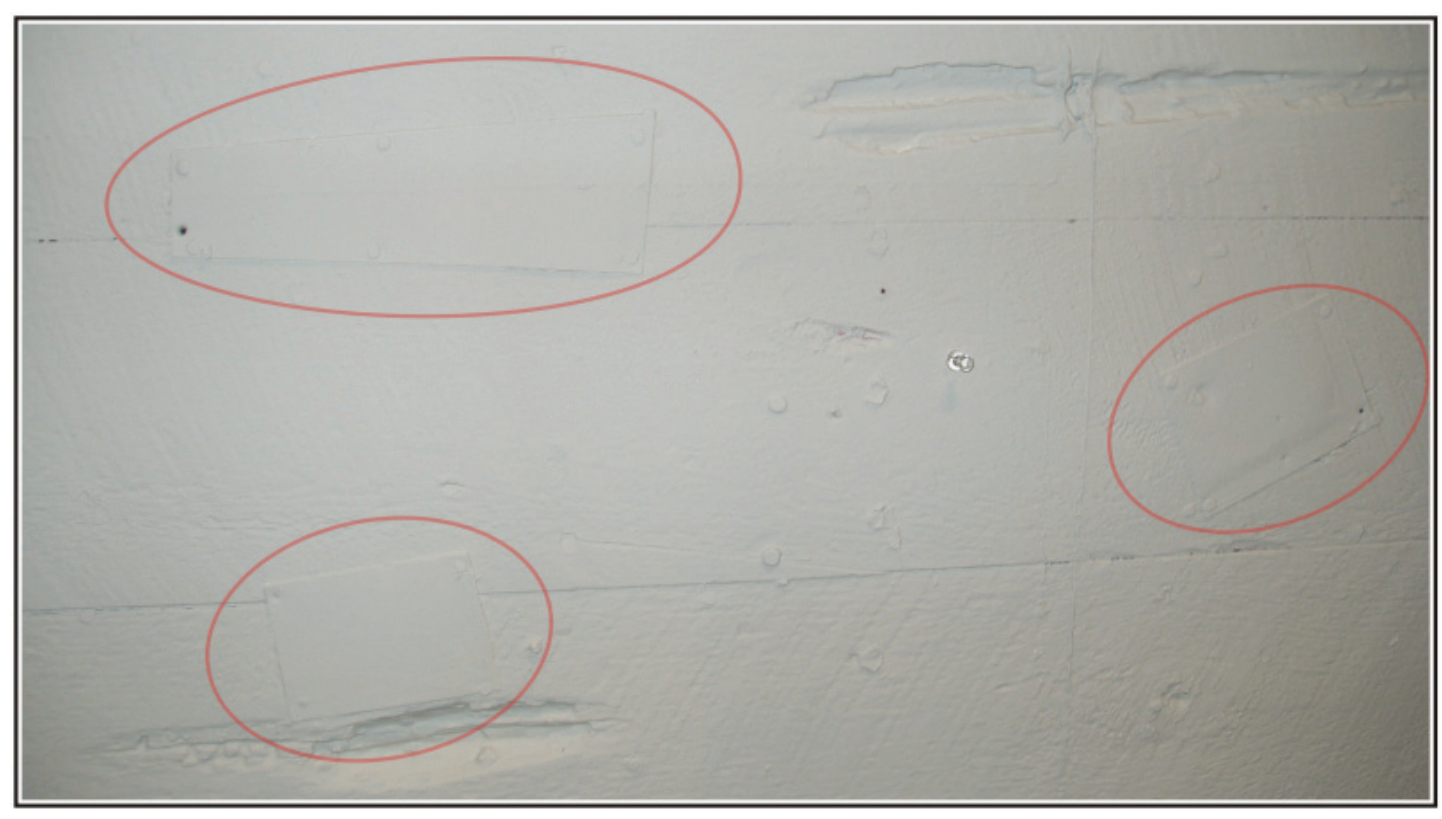

Figure 6-12. Historic makeshift repair work on 1408 Chestnut structure's interior walls. 


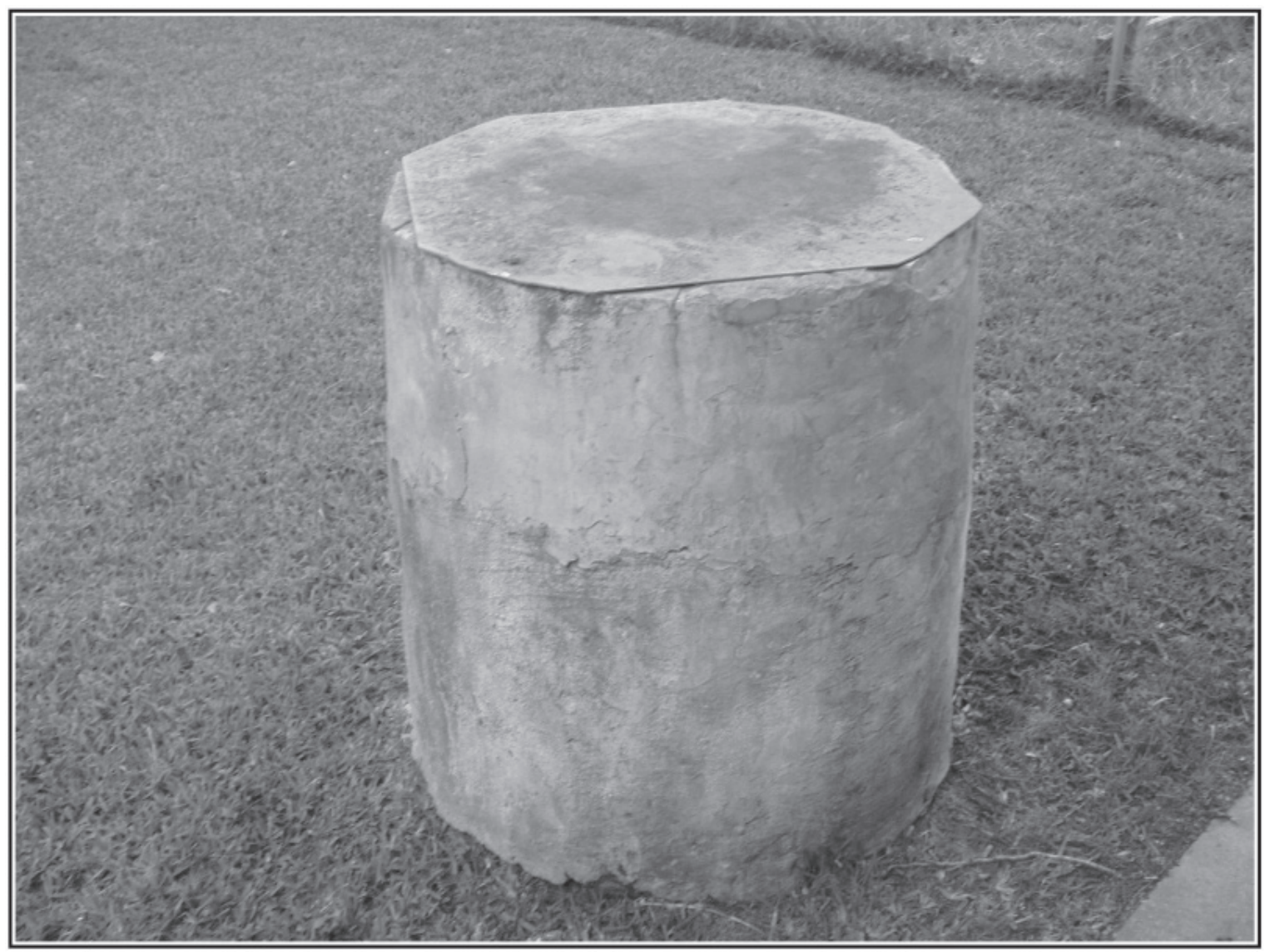

Figure 6-13. Well associated with 1408 Chestnut structure.

Figure 6-1). Minimally diagnostic milk glass and "old" amber glass also suggest the recovered materials are associated with activities dating from the 1870 s to the 1920s. These materials may be associated with what appears to be a railroad freight depot, as seen in Augustus Koch's 1887 depiction of this area (see Figure 6-1). Also of note, Sanborn maps indicate the presence of a dwelling in proximity to 41BP837 as early as 1921, and standing at least until 1944. 41BP837 may be related to activities pertaining to this dwelling, erected sometime between 1887 and 1921, which also correlates with the diagnostic artifacts recovered. However, the construction of the berm east of the railroad coupled with the numerous road-base episodes throughout Block 53 have significantly disturbed the integrity of 41BP837.

\section{Inventory of Non-Historic Structures within the APE}

Seven registered addresses exist within the Area of Potential Effect at the time of this report's publication (see Figure 6-8). The following construction dates were obtained through the Bastrop City Appraisal District database. Based on these construction dates and various architectural characteristics, eligibility for the NRHP for these properties has been determined to be unwarranted.

The western half of Block 52 contains a metal-clad shop building, small kiosk and one foundation (Figure 6-14) built in 1969 and associated with a welding business at 1302 Chestnut Street (BCAP 2008:R47715). The eastern half of Block 52 contains the "Farmers Market" pavilion structures (Figure 6-15) that date to 2004 (BCAD 2008:R35577). This property address, 1308 Chestnut Street, is listed twice as both a residential and commercial property, but no residential structures are currently present. Two corrugated-metal water towers, situated on wooden platforms, currently rest on the property, but they do not appear to be authentic and are most likely reproductions.

Block 53, in addition to the unregistered "Texas Company" depot, contains a commercial garage structure in the northeast corner at 910 Martin Luther King Street (Figure 6-16). It was constructed in 1960 (BCAD 2008:R35585) and is presently in poor condition. Block 69 contains the above 


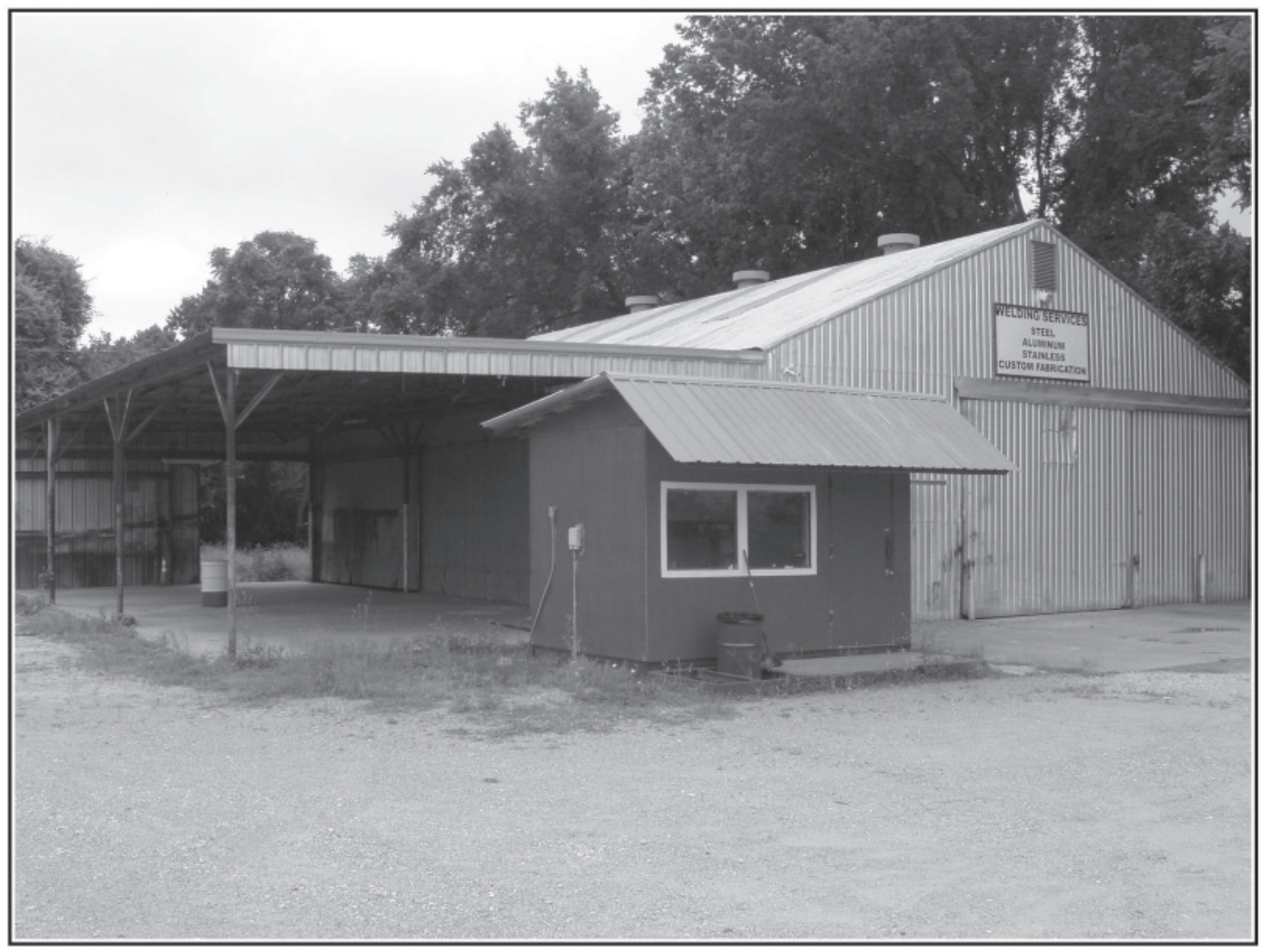

Figure 6-14. Commercial structures present at 1302 Chestnut Street.

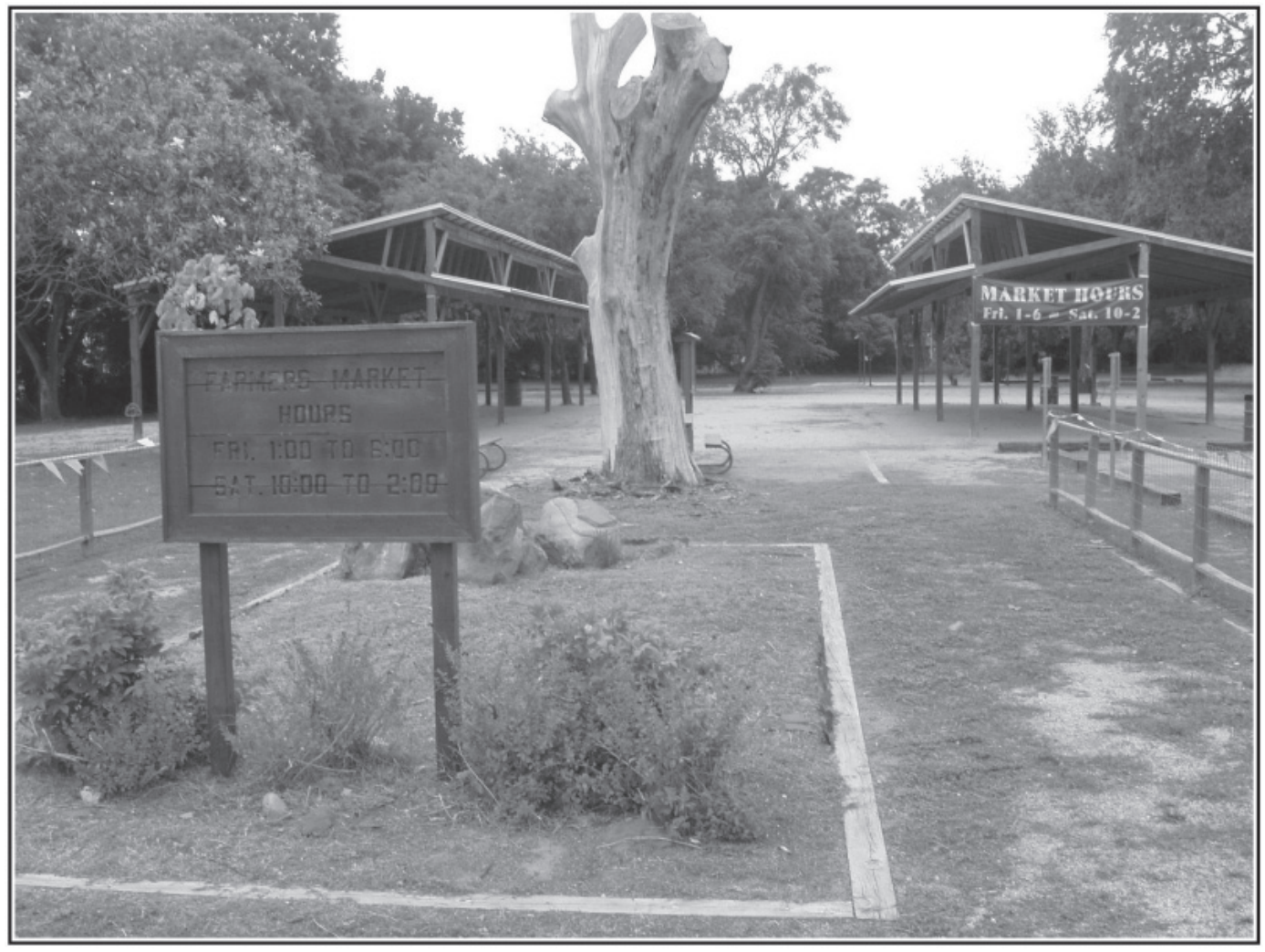

Figure 6-15. Farmer's Market pavilion structures at 1308 Chestnut Street. 


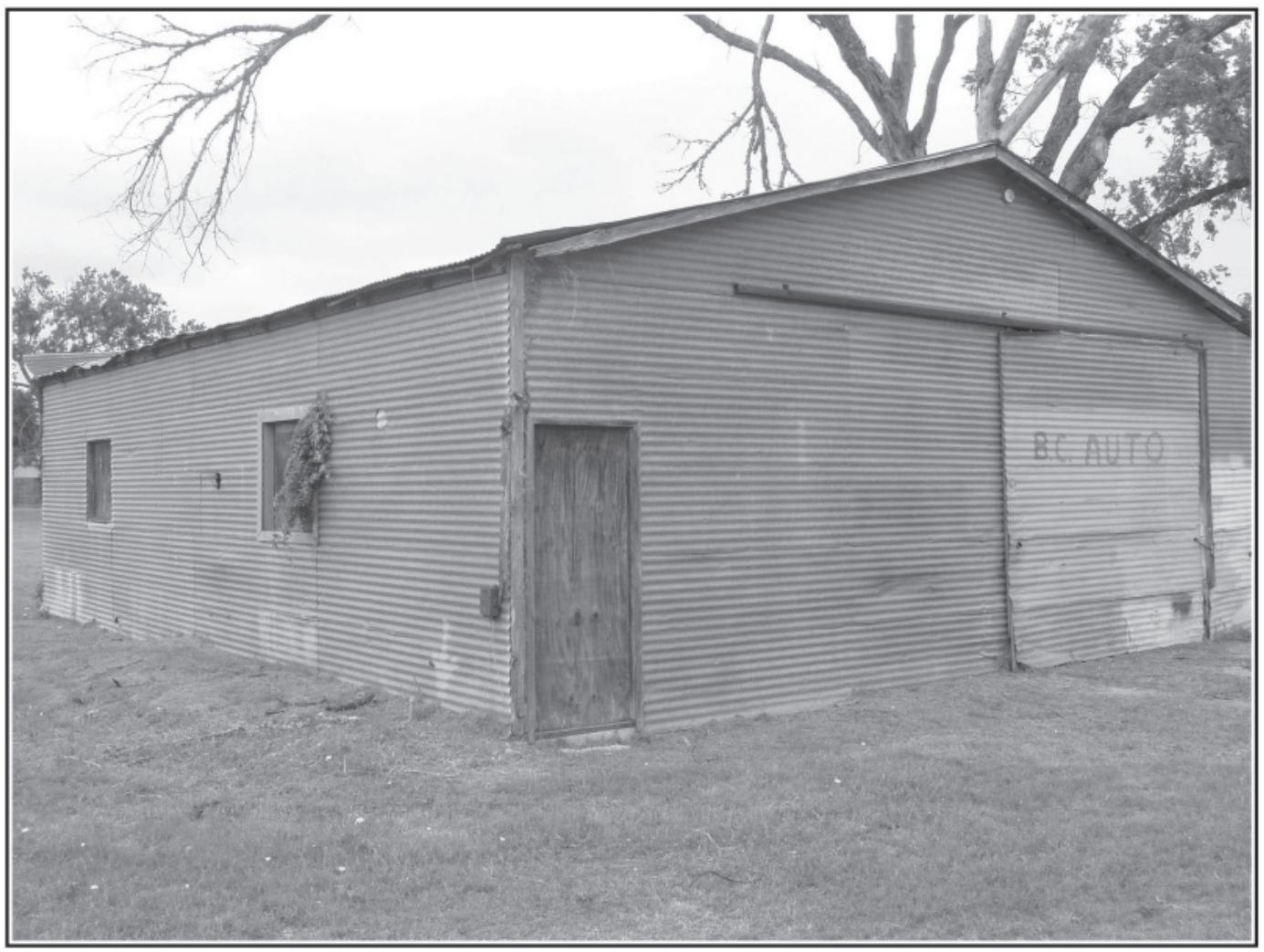

Figure 6-16. Commercial Structure at 910 Martin Luther King Drive.

mentioned historic structure at 1408 Chestnut Street, and it also contains the cement foundation of the old Texas Highway Department building that has long since been removed at 1404 Chestnut Street (Figure 6-17). Only the foundation of this structure remains. Finally, Block 70 has one listed address, 1317 Farm Road, with two commercial garage structures (Figures 6-18 and 6-19), both built in 1977 (BCAD 2008:R47764).

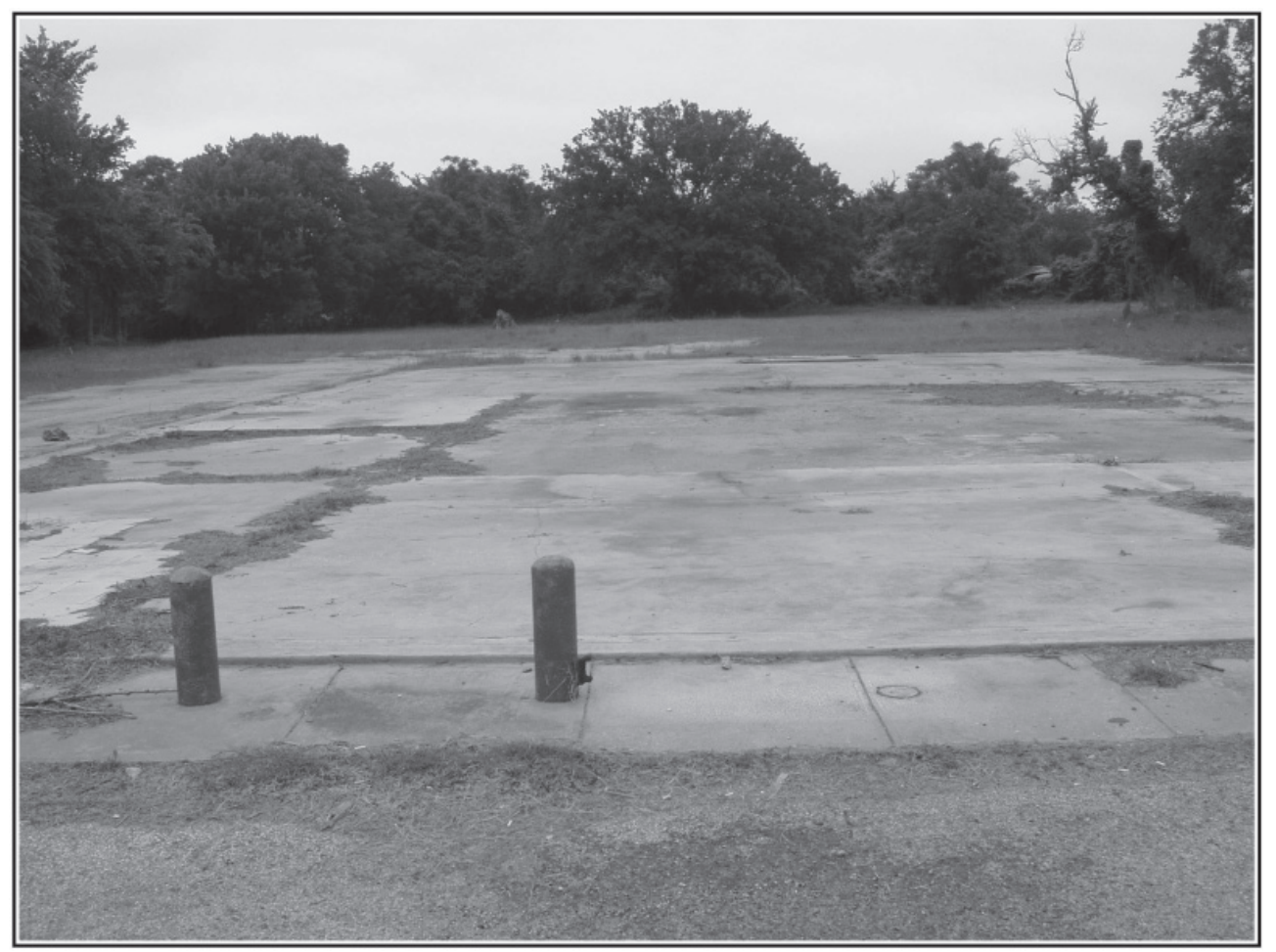

Figure 6-17. Foundation remnants of structure removed from 1404 Chestnut Street. 


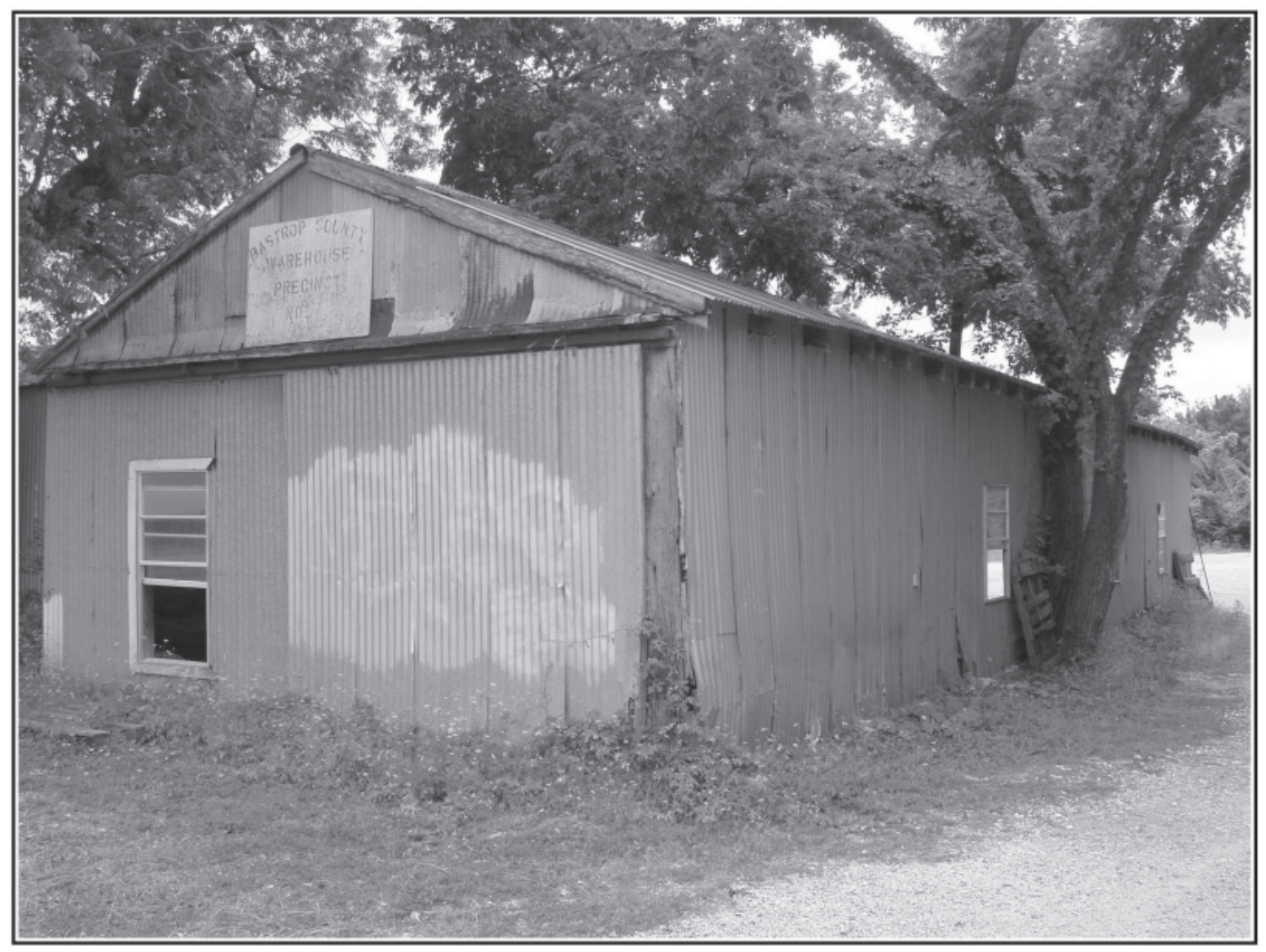

Figure 6-18. Commercial structure at 1317 Farm Road.

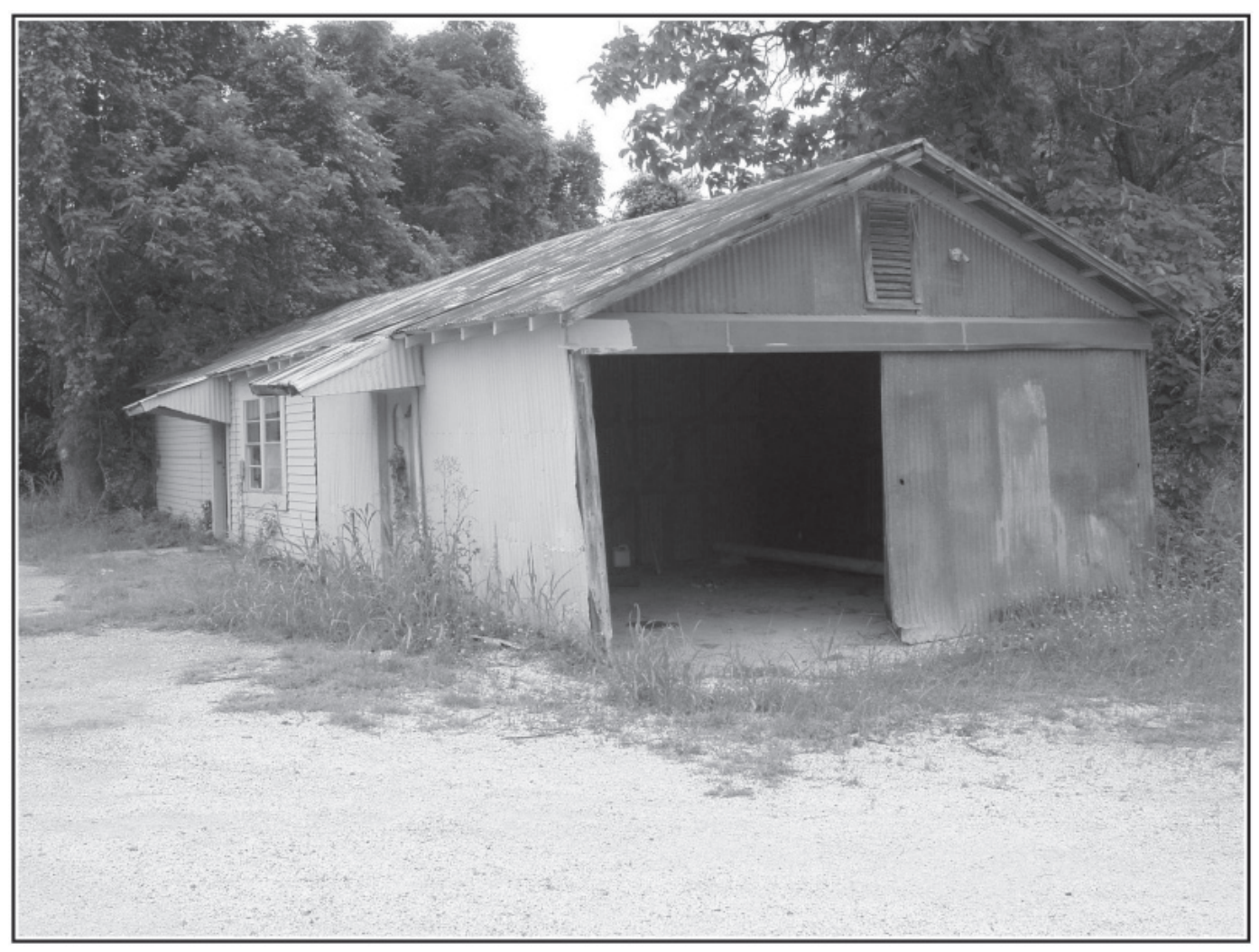

Figure 6-19. Second commercial structure at 1317 Farm Road. 


\section{Chapter 7: Conclusions and Recommendations}

CAR conducted an intensive archaeological pedestrian survey of the proposed Bastrop Convention Center and City Hall project area consisting of four city blocks in order to determine the presence and location of any archaeological material, and to complete a historic structures assessment. A historic archaeological site, 41BP837, was recorded in the northeast quadrant of Block 53, just east of the railroad berm. The size of the site is limited, less than 20 meters sq., and it is situated on a highly disturbed landscape. Based on the marginal diagnostic utility of the recovered bottle glass, the site most likely dates to the late $19^{\text {th }}$ or early $20^{\text {th }}$ century. Recovered cultural materials may be associated with either a railroad depot that was present in 1887, or a dwelling present as early as 1921. Due to the numerous indications of subsurface disturbances in the northwest quadrant of Block 53 (Figure 7-1), and the limited diagnostic value of the archaeological materials it contains, the CAR recommends that the site is ineligible for the NRHP and therefore, further archaeological work on site 41BP837 is not recommended.

Two structures were assessed for eligibility to the NRHP. The structure (41BP839) in the southwest corner of Block 53 with the logo "The Texas Company, USA, Texaco Petroleum Products" is a historic petroleum parts depot dating back to the 1930s. It was moved from its original location, which was the southwest corner of Block 52 (BCCO 1932:99). Ordinarily, structures that have been moved from their original locations and removed from their context are not eligible for the National Register of Historic Places. However, the "Texas Company" depot is the only surviving structure associated with the historic establishment of big oil and gas companies (i.e. "Texaco") in the Historic District of Bastrop County. This structure might have significant cultural relevance to Bastrop's industrial past. Documentation on the "Texas Company's" initial presence in Texas is scarce, but according to the previous owner, the structure is one of the original seventeen fuel distribution stations in Texas before more standardized gaspump filling stations became the norm in the 1950s (Martha "Pinky" Smith, personal communication). Furthermore, this structure also contributes to the nostalgic ambience of Bastrop's Historic District, and its preservation is worth considering. Therefore, the CAR recommends that the "Texas Company" structure in the southwest quadrant of Block 53 is eligible for the National Registry of Historic Places. Given that the depot will be impacted by the proposed construction, the CAR recommends that the City of Bastrop move this building to a location that maintains its relationship to the nearby railroad tracks before construction activities commence. The CAR also recommends the City of Bastrop follow the Secretary of Interior's "Standards for the treatment of Historic Buildings" during the proposed relocation.

The residential structure at 1408 Chestnut Street in the southeast corner of Block 69 is of a dogtrot architectural design, and records indicate that it dates back to at least 1880 (BCAD 2008:R36249). However, numerous renovations and improvements have taken place within, and outside the structure, which detract from its original architectural characteristics. It does not sufficiently meet criteria for listing within the National Register and the CAR recommends that the structure is not eligible for the NRHP.

In sum, archaeological work within the project area of the proposed Bastrop City Hall and Convention Center was successfully conducted in accordance with the Antiquities Code of Texas. The CAR recommends that the City Hall and Convention Center project be allowed to proceed, following the development of a plan of action to protect and move the

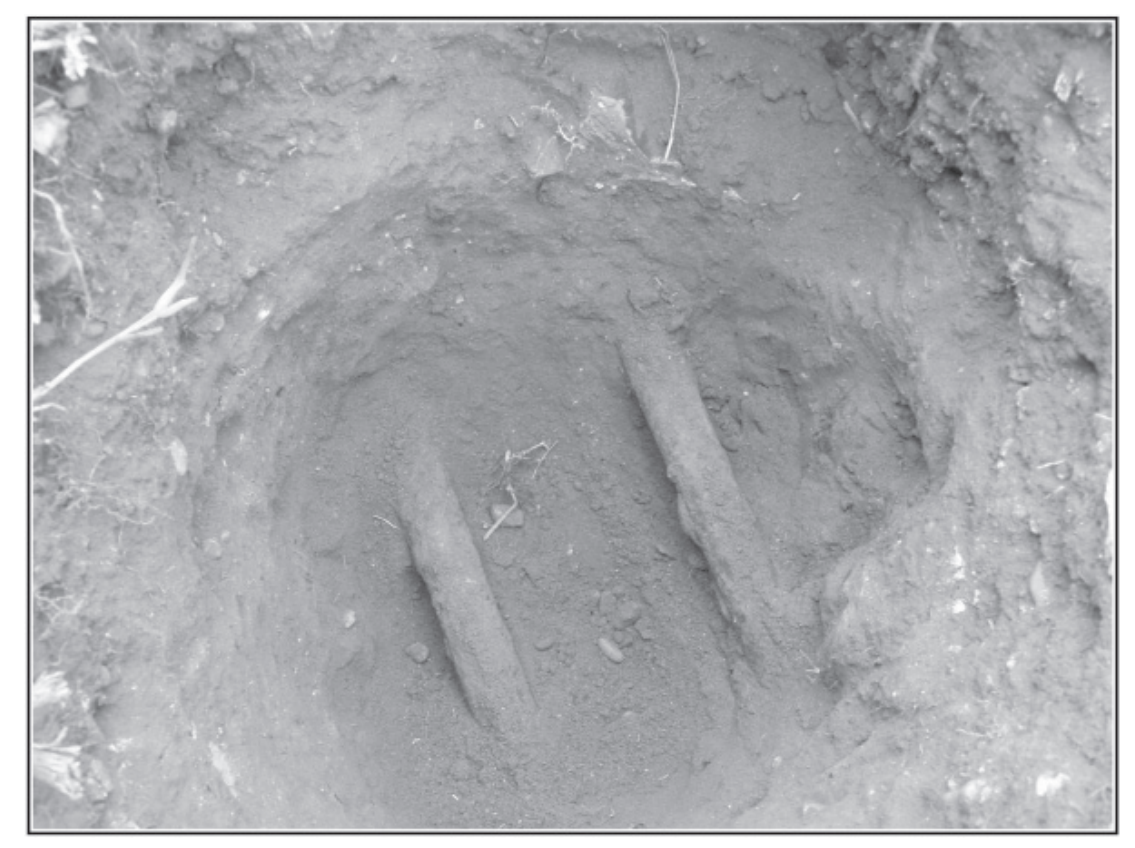

Figure 7-1. Documented subsurface disturbance in Block 53. 
historic “Texas Company” depot structure in the southwestern most corner of Block 53 to a location in proximity to the railroad.

Upon review of this report, The Texas Historical Commission (THC) concluded that 41BP839, the historic railway depot, due to substantive structural modification, is not eligible for listing on the NRHP. No action to preserve the depot is necessary from the City of Bastrop. Furthermore, the THC recommended additional in depth archival research for both Blocks 53 and 69 to determine the exact date of origins of the structures that are pictured on the 1887 Koch bird's eye view map (see Figure 6-1; see Appendix I for a copy of the THC report comments).

Upon completion of further deed research, the CAR concluded that structures previously located on Blocks 53 and 69 were constructed prior to 1880. Land deed records for the property containing the current structure at 1408 Chestnut Street in Block 69 indicate that improvements to the property were made in 1865 (BCCO 1865). Also, a deed from 1857 includes mention of "rights, members, improvements, hereditaments and appurtenances” pertaining to Block 69 (BCCO 1857). Land deed records were located for Block 53 indicating that improvements were made in 1874 to the southeast quadrant of the block (BCCO 1873). Because both blocks contain structures with construction dates prior to 1880 , further testing at the locations of the structures is warranted. The CAR is currently designing a testing plan of the locations of the structures to allow a determination of NRHP eligibility of cultural materials prior to the construction of the Bastrop Convention Center. 


\section{References Cited}

(ACM) Amon Carter Museum- Texas Bird's Eye Views

$2008 \mathrm{http} / / /$ www.birdseyeviews.org/zoom.php?city=Bastrop\&year=1887\&extra_info=. Accessed on April 9, 2008.

Baker, F.E.

1979 Soil Survey of Bastrop County. United States Department of Agriculture Soil Conservation Service in cooperation with the Texas Agricultural Experiment Station. College Station.

(BCAD) Bastrop City Appraisal District

2008 http:www.Bastropcad.org. Accessed on April 9, 2008.

(BCCO) Bastrop County Clerk's Office

1857 Book K, pp 556. Bastrop County Clerk’s Office, Room 112. Bastrop.

(BCCO) Bastrop County Clerk's Office

1865 Book N, pp 32. Bastrop County Clerk’s Office, Room 112. Bastrop.

(BCCO) Bastrop County Clerk's Office

1873 Volume T, pp 127-128. Bastrop County Clerk’s Office, Room 112. Bastrop.

(BCCO) Bastrop County Clerk's Office

1932 Records on file in Bastrop County Clerk's Office, Room 112. Bastrop.

Bement, L.C.

1989 Excavations at 41BP19: The Kennedy Bluffs Site, Bastrop County, Texas. Texas Archaeological Research Laboratory, The University of Texas at Austin. Contract Reports in Archaeology, Report No. 5, Highway Design Division, Texas State Department of Highways and Public Transportation, Austin.

Biesaart, L., W. Roberson, and L. Spotts

1985 Prehistoric Archaeological Sites of Texas. Office of the State Archaeologist 28. Texas Historical Commission. Austin.

Black, S.L.

1989 Central Texas Plateau Prairie. In From the Gulf to the Rio Grande: Human Adaptation in Central, South, and Lower Pecos Texas, by T.R. Hester, S.L. Black, D.G. Steele, B.W. Olive, A.A. Fox, K.J. Reinhard, and L.C. Bement, pp. 1736. Research Series No. 33. Arkansas Archeological Survey, Fayetteville.

Black, S.L., and D.G. Creel

1997 The Central Texas Burned Rock Midden Reconsidered. In Hot Rock Cooking on the Greater Edwards Plateau: Four Burned Rock Midden Sites in West Central Texas, by S. Black, L.W. Ellis, D.G. Creel, and G.T. Goode, pp.269-305. Studies in Archeology 2. Texas Archeological Research Laboratory, The University of Texas at Austin.

Black, S.L., and A.J. McGraw

1985 The Panther Springs Creek Site: Cultural Change and Continuity within the Upper Salado Creek Watershed, SouthCentral Texas. Archeological Survey Report, No. 100. Center for Archaeological Research, The University of Texas at San Antonio. 
Campbell, T.N.

1983 Coahuiltecans and Their Neighbors. In Handbook of North American Indians, Vol. 10, edited by W.C. Sturtevant, pp. 343-358. Smithsonian Institution, Washington, D.C.

Collins, M.B.

1995 Forty Years of Archeology in Central Texas. Bulletin of the Texas Archaeological Society 66:361-400.

(DSM) Digital Sanborn Maps 1867-1970

2008 Bastrop County, Texas. http://sanborn.umi.com/tx/8421/dateid-000007.htm?CCSI=1009n Accessed on April 9, 2008.

Driver, D.

2006 A Cultural Resource Survey of 28 Acres for the Colorado River Sanctuary, Bastrop County, Texas. Report of Investigations, No. 478. Moore Archaeological Consulting, Inc.

Figueroa, A.L.

2006 Archaeological Testing at 41BP678, Bastrop County, Texas. Archaeological Report, No. 364. Center for Archaeological Research, The University of Texas at San Antonio.

Godfrey, C.L. and others

1973 General Soil Map of Texas. Texas A\&M University. College Station.

Godwin, M.F.

2005 An Archaeological Survey of the Proposed Kerr Community Park, Bastrop County, Texas. Survey Report 47. Antiquities Planning \& Consulting, Kyle, Texas.

Godwin, M.F. and J.W. Clark, Jr.

2005 A Cultural Resources Survey of the Bastrop County Park at Cedar Creek, Texas, Bastrop County. Survey Report 49. Antiquities Planning \& Consulting, Kyle, Texas.

Hester, T.R.

1989 Historic Native American Populations, in From the Gulf to the Rio Grande: Human Adaptation in Central, South, and Lower Pecos Texas, by T.R. Hester, S.L. Black, D.G. Steele, B.W. Olive, A.A. Fox, K.J. Reinhard, and L.C. Bement, pp. 77-84. Research Series No. 33. Arkansas Archeological Survey, Fayetteville.

1995 The Prehistory of South Texas. Bulletin of the Texas Archeological Society 66:427-459.

Jenkins, J.H.

1958 Recollections of Early Texas. University of Texas Press, Austin.

Johnson, L.

1994 The Life and Times of Toyah-Culture Folk: The Buckhollow Encampment, Site 41KM16, Kimble County, Texas. Office of the State Archeologist Report 38. Texas Department of Transportation and Texas Historical Commission, Austin.

Kendrick, G.

1968 The Mouth-Blown Bottle. Edwards Brothers, Ann Arbor. 
Kesselus, $\mathrm{K}$.

1986 History of Bastrop County, Texas: Before Statehood. Jenkins Publishing Company, Austin.

Lohse, J.C., and C.B. Bousman

2006 National Register Evaluation of Eight Sites at Camp Swift Army National Guard Training Center, Bastrop County, Texas: Swift. Archaeological Studies Report No. 8. Center for Archaeological Studies, Texas State University at San Marcos.

McAlester, V. and L. McAlester

1984 A Field Guide to American Houses. Alfred A. Knopf, Inc., New York.

McGraw, A.J., J.W. Clark, and E.A. Robins

1998 A Texas Legacy The Old San Antonio Road and the Caminos Reales a Tricentennial History, 1691-1991. Texas Department of Transportation. Austin.

Meltzer D.J., and M.R. Bever

1995 Paleoindians of Texas: An Update on the Texas Clovis Fluted Point Survey. Bulletin of the Texas Archaeological Society 66:47-81.

McKinney, W.W.

1981 Early Holocene Adaptations in Central and Southern Texas: The Problem of the Paleoindian-Archaic Transition. Bulletin of the Texas Archaeological Society 52:91-120.

Moore, B.

1977 Bastrop County 1691-1900. Nortex Press, Wichita Falls.

Moses, B.K.

2004 An Archaeological Survey of the Proposed Location of the Bastrop City Wastewater Treatment Plant, Bastrop County, Texas. Archaeological Survey Report, No. 353. Center for Archaeological Research, The University of Texas at San Antonio.

Munoz, C.M.

2006 Archaeological Testing at 41BP679, Bastrop County, Texas. Archaeological Report, No. 366. Center for Archaeological Research, The University of Texas at San Antonio.

Nickels, D.L., M.L. Lehman, and C.B. Bousman

2003 Archaeological Evaluation of 39 Category V Sites at Camp Swift, Bastrop County, Texas. Archaeological Studies Report No. 3. Center for Archaeological Studies, Southwest Texas State University, San Marcos.

Perttula, T.K., M.R. Miller, R.A. Ricklis, D.J. Prikryl, and C. Lintz 1995 Prehistoric and Historic Aboriginal Ceramics in Texas. Bulletin of the Texas Archeological Society 66:175-235.

Prewitt, E.R.

1981 Culture Chronology in Central Texas. Bulletin of the Texas Archeological Society 52:65-89.

Renfro, H.B.

1979 The Geological Highway Map of Texas. The American Association of Petroleum Geologists, Tulsa. 
Ricklis, R.A.

1992 The Spread of the Late Prehistoric Bison Hunting Complex: Evidence from the South-Central Coastal Prairie of Texas. Plains Anthropologist 37(140):261-273.

(SHA) Society for Historical Archaeology- Historic Glass Bottle Identification \& Information Website 2008 http://www.sha.org/bottle/colors.htm. Accessed on April 9, 2008.

Story, D.A.

1985 Adaptive Strategies of Archaic Cultures of the West Gulf Coastal Plain. In Prehistoric Food Production in North America, edited by R.I. Ford, pp. 19-56. Anthropological Papers No. 75. Museum of Anthropology, University of Michigan, Ann Arbor.

Sumerlin, W.O.

1963 The History of Bastrop, Texas (1851-1935). Masters Thesis at The University of Texas at Austin.

de la Teja, J.F.

1998 The Camino Real Colonial Texas' Lifeline to the World. In A Texas Legacy The Old San Antonio Road and the Caminos Reales a Tricentennial History, 1691-1991. Texas Department of Transportation, Austin.

(THC) Texas Historical Commission Archaeological Site Atlas

2008 Bastrop Commercial District. http://nueces.thc.state.tx.us/common/view narrative.asp?narrative=78003262.htm\&title=Bastrop\%20 Commercial\%20District\&filepath=E:latlas texthn_listedhtml. Accessed on April 9, 2008.

(HTO) Texas State Historical Association- The Handbook of Texas Online

2008 http://www.tsha.utexas.edu/handbook/online/. Accessed on April 9, 2008.

Turner, S.E., and T.R. Hester

1993 Stone Artifacts of Texas Indians. Second Edition. Texas Monthly and Gulf Publishing Company, Houston.

University of Utah- Bottle section - Part 472

1982 http://www.anthro.utah.edu/imacs.html. Accessed on April 9, 2008.

Webb, W.P. (editor)

1952 The Handbook of Texas. 2 Vols. Texas State Historical Association, Austin.

Weir, F.A.

1976 The Central Texas Archaic. Unpublished Ph.D. dissertation. Department of Anthropology, Washington State University, Pullman. 
Appendix I

Texas Historical Commission Recommendations 



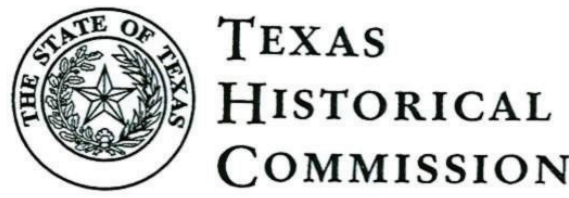

The State Agency for Historic Preservation
RICK PERRY, GOVERNOR

JOHN L. NAU, II, CHAIRMAN

F. LAWERENCE OAKS, EXECUTTVE DIRECTOR

July 15,2008

Steve A. Tomka, Ph.D.

Center for Archeological Research

University of Texas at San Antonio

6900 North Loop 410 West

San Antonio, TX 78249-0658

Re: Project review under the Antiquities Code of Texas, Antiquities Permit \# 4867, Survey of Proposed Bastrop Convention Center, Draft Report (City of Bastrop)

Dear Dr. Tomka:

Thank you for your correspondence concerning the above referenced project. This letter presents the comments of the Executive Director of the Texas Historical Commission (THC), the state agency responsible for administering the Antiquities Code of Texas. We have reviewed the Draft Report for Antiquities Permit \# 4867, and while we have reached one conclusion regarding your eligibility recommendation for "Texas Company" structure, additional archival research and possible additional field investigations are warranted for Blocks 53 and 69.

With regard to UTSA's eligibility recommendation for the Texas Company structure, the THC believes that because this structure has been substantively modified in the past, it is not eligible. Furthermore, we believe additional in depth archival research is needed for both Blocks 53 and 69, to determine the exact date of origin of the structures that are pictured in the 1887 Koch bird's eye view map of those blocks. If these residences date prior to 1880 , testing at the location of the structure that stands at the corner of Marion and Chestnut within Block 53 and the location of the two structures with Block 69, is warranted.

Thank you for your cooperation in this state review process, and for your efforts to preserve the irreplaceable heritage of Texas. If you have any questions please contact Mark H. Denton, of our staff at (512) 463-5711.

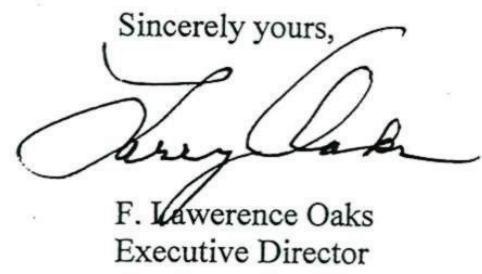

LO/MHD 
